\title{
Bank Capital Pressures, Loan Substitutablity, and Nonfinancial Employment
}

Lee, Seung Jung, and Viktors Stebunovs

Please cite paper as:

Lee, Seung Jung and Viktors Stebunovs (2016). Bank Capital

Pressures, Loan Substitutability, and Nonfinancial Employment

International Finance Discussion Papers 1161

http://dx.doi.org/10.17016/IFDP.2016.1161

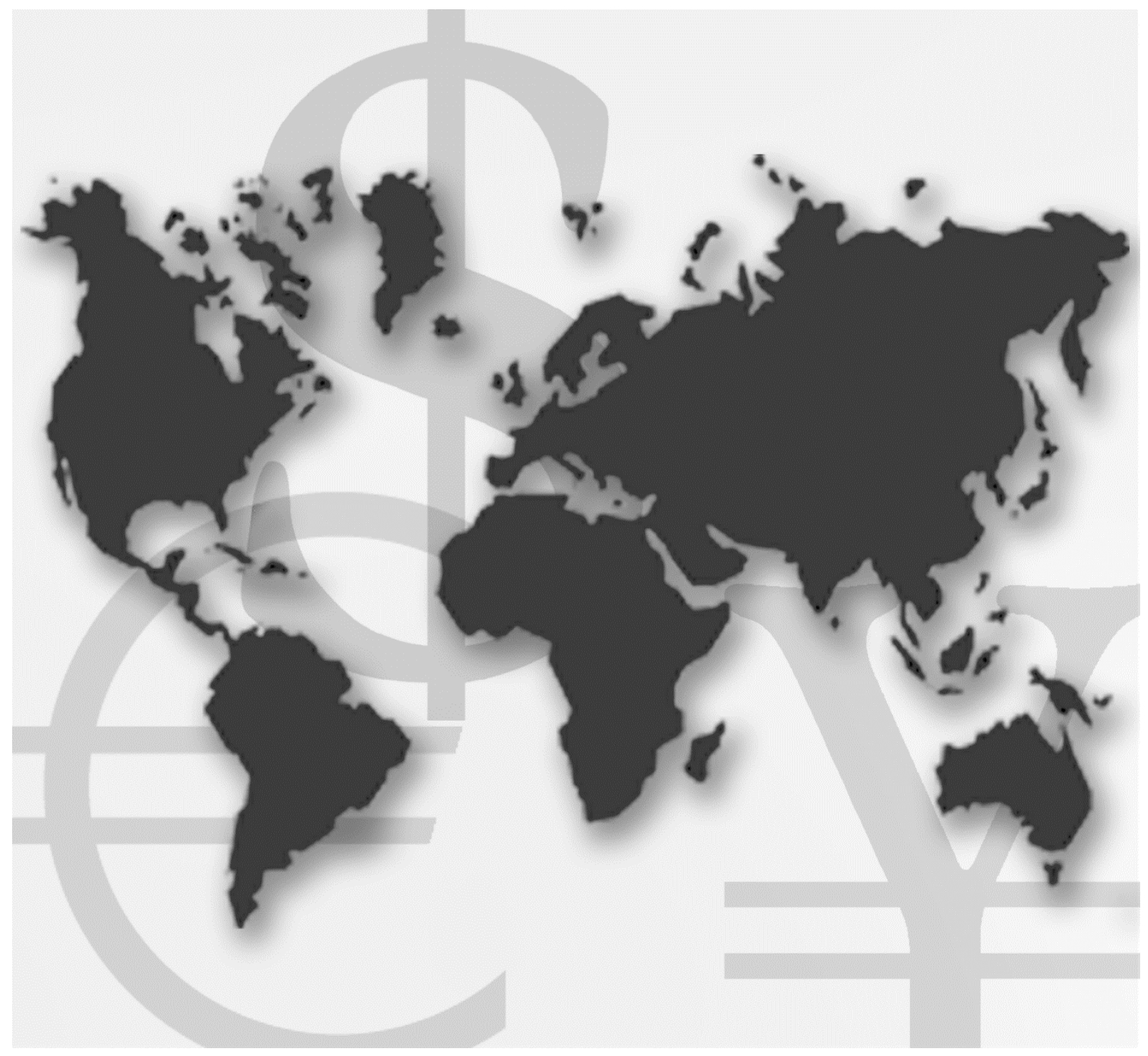

\section{International Finance Discussion Papers}

Board of Governors of the Federal Reserve System

Number 1161

April 2016 
Board of Governors of the Federal Reserve System

\author{
International Finance Discussion Papers
}

Number 1161

April 2016

Bank Capital Pressures, Loan Substitutability, and Nonfinancial Employment

\author{
Seung Jung Lee \\ Viktors Stebunovs
}

NOTE: International Finance and Discussion Papers are preliminary materials circulated to stimulate discussion and critical comment. References in publications to International Finance Discussion Papers (other than an acknowledgment that the writer has had access to unpublished material) should be cleared with the author or authors. Recent IDFPs are available on the Web at www.federalreserve.gov/pubs/ifdp/. This paper can be downloaded without charge from Social Science Research Network electronic library at www.ssrn.com. 
Bank Capital Pressures, Loan Substitutability, and Nonfinancial Employment

\author{
Seung Jung Lee ${ }^{\dagger}$ \\ Viktors Stebunovs ${ }^{\ddagger}$
}

Abstract: We exploit the cross-state, cross-time variation in bank tangible capital ratios - brought about by bank branch deregulation on a state-by-state basis - to identify the effects of bank capital pressures on employment and firm dynamics during two waves of changes in bank capital regulation. We show that stronger capital pressures temporarily slowed down growth in employment in industries that depend on external finance, retarding growth in the average size of firms rather than in the number of firms. Such effects were particularly strong for smaller firms that may not have had access to national capital and bank loan markets. Our findings indicate that a tightening of capital requirements may have significant real effects, in part because of the lack of substitutes for bank loans.

Keywords: Bank capital ratios; bank capital regulation; loan substitutability; employment; firm dynamics.

JEL Classifications: G21, G28, G30, J20, L25.

$\dagger$ Board of Governors of the Federal Reserve System, 20th Street and Constitution Avenue, NW, Washington, DC 20551, U.S.A.; seung.j.lee@frb.gov. URL: http: //www.federalreserve.gov/econresdata/seung-jung-lee.htm.

$¥$ Board of Governors of the Federal Reserve System, 20th Street and Constitution Avenue, NW, Washington, DC 20551, U.S.A.; viktors.stebunovs@frb.gov. URL: http://www.federalreserve.gov/econresdata/viktors-stebunovs.htm.

The views in this paper are solely the responsibility of the authors and should not be interpreted as reflecting the views of the Board of Governors of the Federal Reserve System or of any other person associated with the Federal Reserve System. We are grateful to an anonymous referee for valuable comments and suggestions. We thank Elizabeth Kiser for access to the Summary of Deposits data. The paper is forthcoming in the Journal of Economics and Business. 


\section{Introduction}

In the aftermath of the global financial crisis, commercial banks significantly improved their capital positions, which raised concerns that their actions might have contributed to the modest growth in bank loans and the sluggish economic recovery. Historically, commercial banks increase their capital ratios-for example, because of stricter capital requirements and stronger supervisory pressures - by tightening lending standards and terms and, therefore, limiting the supply of bank loans. And a tightening of access to bank loans may have significant real effects, in part because of the lack of substitutes for bank loans. Such effects may be particularly strong for firms in industries that depend on external sources of finance and, within these industries, for smaller firms that may not have access to national capital and bank loan markets.

In this paper, we examine the effects of bank capital pressures on employment and firm dynamics during two waves of changes in bank capital regulation in the United States. The first wave, in the late 1970s and mid-1980s, included the introduction of numerical capital standards that varied by type (size) of commercial banks. The second wave, in the early 1990s, included the introduction of the Basel I and leverage ratio requirements and the passing of the Federal Deposit Insurance Corporation Improvement Act (FDICIA) 1 Over these decades, many factors might have contributed to commercial banks' capital pressures, but stricter capital requirements, as the literature and our evidence suggest, likely played a major role.

We exploit the cross-state, cross-time variation in bank tangible capital ratiosbrought about by bank branch deregulation on a state-by-state basis - to identify the effects of bank capital pressures on employment and firm dynamics. Over our sample period, geographical restrictions on bank branching across state borders were removed on a state-by-state basis. Because of the way deregulation unfolded, as the literature suggests, banks expanded into new geographic markets in a random fashion. $2^{2}$ Many of these out-of-state banks tended to be relatively large and, therefore, immune to economic conditions in their new geographical markets. In other words, the randomized presence of out-of-state banks provides exogenous variation in capital pressures in these new markets that we can use for identification. Our way to address

\footnotetext{
${ }^{1}$ These later changes in regulations did not vary by type (size) of commercial banks.

${ }^{2}$ See, for example, Goetz, Laeven, and Levine (2013).
} 
possible reverse causality between bank capital pressures and local economic conditions is similar to that of Peek and Rosengren (2000), who study the effects of the Japanese banking crisis on construction activity in the U.S. commercial real estate market 3

While bank capital pressures likely affect employment and firm dynamics in many industries, we focus only on manufacturing industries. The reliance of these industries on external sources of finance for capital expenditures appears to have changed little over the years ${ }^{4}$ As in Cetorelli and Strahan (2006), among 20 manufacturing industries, we identify industries that depend on external finance more than the others do $5^{5}$ In our empirical work, this differentiation allows us to control for omitted variable bias - for example, the bias that arises from technological changes that drive both banking regulation and nonfinancial employment dynamics.

Controlling for branch deregulation, bank concentration, demand factors at state and industry levels, and omitted variable bias, we show that capital pressuresmanifested through positive changes in bank capital ratios over the two waves of capital regulation - resulted in a temporary slowdown in growth of employment and the average size of firms, but not in the growth of the number of firms. While establishing a new firm may require a small outlay (as incorporation costs are very modest), hiring and maintaining staff does not, in part because of the complementarity of labor and physical capital. Acquiring and maintaining physical capital is costly, and therefore capital expenditure likely requires external funding — for example, bank loans. The effects of bank capital pressures on employment are particularly strong for smaller firms that may not have access to national capital and bank loan markets. Therefore, our findings indicate that a tightening of capital requirements may have significant real effects, in part because of the lack of substitutes for bank loans.

Our paper belongs to a couple of the literature strands. First, we contribute to the labor-finance literature. While Benmelech, Bergman, and Seru (2011) show that financial constraints and the availability of credit play an important role in firm-level employment decisions for large, public firms, as well as in aggregate unemployment

\footnotetext{
${ }^{3}$ Other papers that address possible reverse causality by looking at large, remote banks' activities in small locations include Garmaise and Moskowitz (2006), that study the effects of changes in large bank mergers on changes in crime at the MSA level.

${ }^{4}$ For example, see the appendix in Haltenhof, Lee, and Stebunovs (2014).

${ }^{5}$ This distinction is based on Rajan and Zingales (1998)'s measures of dependence on external finance for mature firms because their financial decisions likely reflect technological rather than financial constraints.
} 
outcomes at a state level, Cetorelli and Strahan (2006) and others demonstrate, using industry-level data that include even the smallest of firms, that competition in banking and other factors affecting access to bank credit explain employment and firm dynamics in industries that depend on external finance. In the spirit of the latter, we use industry-level data for U.S. manufacturing industries and focus on those industries that depend on external sources of finance. Second, we contribute to the literature that studies the effects of changes in bank capital regulation on lending. While papers in this literature strand typically do not consider the substitutability of bank loans for nonbank credit and the real effects of changes in capital regulation, we emphasize the lack of the substitutability of bank loans for nonbank credit and the economic significance of the damping effects of bank capital pressures on employment growth.

Our findings have implications for policy decisions in the capital regulation area. Since the global financial crisis, banks in the United States and elsewhere have been making large balance sheet adjustments (in the form of deleveraging) to repair their balance sheets and have been adapting to changes in regulatory capital requirements due to Basel III. These stricter capital standards are set with the hope of buttressing the banking sector to withstand any future crises, but likely with real costs to firms and households.

The outline of the paper is as follows. The second section describes our contributions to the literature. The third section provides a historical review of various capital regulation in the United States. The fourth section describes our data and the construction of the variables of interest. The fifth section goes over our empirical strategy and summary statistics of the main variables. The sixth section presents the estimation results and some robustness checks. Finally, we conclude, and we offer additional robustness checks in the appendix.

\section{Literature}

Our paper mainly belongs to two strands of the literature: the labor-finance literature and the capital regulation literature.

The labor-finance literature The labor-finance literature points out a few reasons why the cost and availability of external finance affect firm employment deci- 
sions ${ }^{6}$ First, when there is a mismatch between payments to labor and the ultimate generation of cash flow, firms will need to finance their labor activity throughout the production process. Second, if labor has a fixed, or a quasi-fixed, cost component that needs to be financed, employment decisions can also be affected by financial constraints. Third, the availability of external finance may affect employment indirectly through its effect on firm-level investment - the channel that is studied the most and which we examine here as well.

The literature often relies on "natural experiments" to identify the labor-finance linkages - for example, to show that changes in access to credit have real effects. Benmelech, Bergman, and Seru (2011) use Compustat data for large firms to show that financial constraints and the availability of credit play an important role in firm-level employment decisions. The same authors employ "quasi-experiments", such as bank branching deregulation in the United States, to trace the effects of finance on unemployment at the state level. Cetorelli and Strahan (2006) show that bank branching deregulation and changes in competition in banking and other factors affecting access to bank credit explain employment and firm dynamics in industries that depend on external finance at an industry-state level 7

In the spirit of these papers, we rely on interstate bank branching deregulation to provide a natural experiment setting and use industry-level data for U.S. manufacturing industries that cover employment even at the smallest of firms. Because of the way deregulation unfolded, the literature suggests, banks expanded into new geographic markets in a random fashion. Many of these out-of-state banks tended to be relatively large and, therefore, immune to economic conditions in their new geographical markets. In other words, the randomized presence of out-of-state banks provides exogenous variation in capital pressures in these new markets that we can use for identification. Differentiating employment by firm-size class is essential because smaller firms have more limited access to external finance and, therefore, employment at these firms may be more susceptible to changes in access to bank loans. Therefore, a tightening of access to bank loans may have significant real effects, in part because

\footnotetext{
${ }^{6}$ The following list does not include firms' suppliers or clients as sources of external finance. These sources may be important for some firms. For example, Haltenhof, Lee, and Stebunovs (2014) find some evidence that the trade credit channel - captured by the interaction of an indicator of dependence on trade credit and the three-month LIBOR - was operational during the most recent financial crisis but that it is not statistically robust.

${ }^{7}$ Cetorelli (2004) also investigates how enhanced bank competition in the E.U. area led to markets in nonfinancial sectors being characterized by lower average firm size in the early 1990s.
} 
of the lack of substitutes for bank loans.

In contrast to these papers, we consider bank capital pressures that, in part, reflect stricter capital regulation and supervisory demands as two of the main factors that affect employment at an industry-state level. We demonstrate that, over the two waves of changes in capital regulation, bank capital pressures had a significant effect on employment and firm dynamics in industries that depend on external finance and, within these industries, on employment and firm dynamics of smaller firms.

We note that, while bank branching deregulation in each state had a well-defined implementation date, lending itself to a straightforward difference-in-difference analysis, the capital regulation process was notably more complex. For example, as in the early 1980s, the changes in capital requirements were gradual and extended for a relatively long period of time.

The capital regulation literature The capital regulation literature, which we contribute to as well, includes a variety of topics. We rely on several papers to relate bank capital pressures primarily to bank capital regulation; to show that banks cut back on lending to deal with capital pressures; and to gauge the potential effects that stricter capital regulation may have on real activities. Papers in this literature typically do not consider the substitutability of bank loans for nonbank credit and the effects of changes in capital regulation on employment and firm dynamics.

Over the last decades, many factors likely contributed to commercial banks' capital pressures, but stricter capital requirements, as the literature suggests, likely played a major role. Wall and Peterson (1987) and Wall and Peterson (1995) argue that capital ratios at the level of bank holding companies (BHCs) are determined by two forcesregulatory forces and market-based forces - and that regulatory forces were likely the predominant factors that explain capital ratio adjustments seen at the large BHCs during the years from 1982 to 1984 and from 1990 to 1992. These periods coincided with the two waves of regulatory tightening of capital adequacy standards, especially for the large banks.

In this context, commercial banks tended to adjust assets - specifically loansrather than issue equity. Myers and Majluf (1984) provide a theoretical justification for such behavior. They argue that banks adjust to higher capital ratios by shrinking assets rather than by issuing new equity because of asymmetric information and the 
lemons problem faced by potential equity investors.$^{8}$ Keeley $(1988)$ presents empirical evidence that, for the largest BHCs, uniform capital requirements introduced in the early 1980s increased the book capital ratios for the capital-deficient banks by adjusting assets rather than capital compared to capital-sufficient banks. Peek and Rosengren (1995) find a strong relationship between adverse capital shocks to banks and the slower growth rate of their deposits as evidence for a capital crunch (to obtain higher capital ratios) in New England during the early 1990s. ${ }^{9}$ Lown and Morgan (2006) show how the tightening of credit standards on commercial and industrial (C\&I) loans was associated with a slowdown in the growth of such loans, particularly prior to the early 1980s and 1990s recessions, which coincided with the two waves of changes in capital regulation mentioned above. As for international evidence, Aiyar, Calomiris, and Wieladek (2014) study the bank-specific changes in minimum capital requirements in the United Kingdom and find a statistically and economically significant effect on lending from 1998 to 2007.

Hancock and Wilcox (1998) also gauge the real effects of bank capital pressures, but with a more limited sample and disaggretion than ours. They look at how changes in the dollar volume of capital over the 1989-92 period affected real economic activity at a state level, such as employment, payrolls, and the number of firms by firm size, with a focus on small businesses. They find that a decline in capital levels at small banks correlates with (rather than causes) larger changes in economic activity dollarfor-dollar than do capital declines at large banks. More recent research on estimating the costs of some of the capital regulation initiatives is limited to the relationship between bank balance sheets and larger borrowers who had access to broader capital markets. Kashyap, Stein, and Hanson (2010) and Kiley and Sim (2011), point to only modest effects of higher minimum capital requirements on loan rates or aggregate output.

The differences between our work and most of these studies are threefold. First, we set to establish a causal effect of bank capital pressures on employment and firm dynamics. Second, our study incorporates employment data even at the smallest of

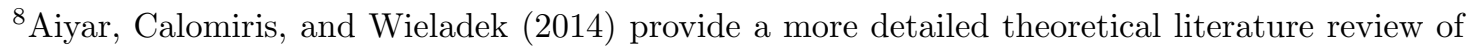
the costs to issuing equity.

${ }^{9}$ They develop a model to demonstrate that, following a negative shock, banks that are capital constrained will reduce both deposits and loans, while unconstrained banks only reduce loans. In their analysis of difficulties in the New England banking sector in the early 1990s, they find a relationship between capital ratios and deposit growth, which they take as evidence that loan supply contracted.
} 
firms, which tend to depend on local bank loans. Third, because of the richness of our data, we can take into account the possible substitution of funding sources. One might imagine that firms will substitute away from more expensive bank funding to cheaper alternatives, perhaps mitigating the effect of higher capital ratios and more expensive bank funding on firms' economic activity. For example, Rice and Strahan (2010) find that more competition across banks improves loan pricing and encourages firms to substitute toward bank debt and away from other sources of debt. In our analysis, to address this issue, we look at the real effects that can be seen from a more complete universe of firms by using the state-level U.S. Census Country Business Patterns data.

\section{Changes in Bank Capital Regulation}

In this section, we describe two waves of changes in bank capital regulation in the United States: One from the late 1970s to the mid-1980s and the other in the early 1990s. The first wave included the introduction of numerical capital standards that varied by type (size) of commercial banks. The second wave included the introduction of the Basel I and leverage ratio requirements and the passing of the FDICIA. These later regulations did not vary by type (size) of commercial banks.

The first wave of changes in capital regulation Capital regulation by the federal bank regulatory agencies in the 1970s was conducted through ad-hoc target capital ratios based on peer-group comparisons along with bank-specific considerations. 10 The secular decline in bank capital levels and the failures of several large banks, however, prompted bank regulators in 1979 to consider enforcing a fixed minimum level of capital relative to assets on the balance sheet.

Though the banking industry resisted such developments at first, because of the concern over banks' foreign debt exposure and exposure to the deteriorating energy industry, the Office of the Comptroller of the Currency (OCC) and the Federal Reserve Board announced minimum capital guidelines in December 1981. Seventeen multinational banks were exempted from this requirement and continued to be regulated and supervised on an ad-hoc basis.11 In August 1983, the guidelines were

\footnotetext{
${ }^{10}$ For more information on capital regulation in the 1980s, see Federal Deposit Insurance Corporation, A History of the 80s: Lessons for the Future, July 28, 1999.

${ }^{11}$ The new guidelines were based on three categories of banks under the supervision of the OCC and the Federal Reserve Board: community banks with assets under $\$ 1$ billion were subject to minimum
} 
amended so that the multinational banks had to adhere to the same minimum capital requirements as regional banks, though prior to the amendment, the multinational banks had already strengthened their capital positions through the prompting of the federal agencies. The International Lending Supervision Act of 1983 empowered the federal financial regulatory agencies, including the FDIC, to uniformly establish and enforce minimum capital requirements for all types of banking institutions beginning in 1985.12 All told, from 1981 to 1985 multinational and regional banks saw their capital requirements increase, whereas community banks saw their capital requirements decrease.

Soon, problems with the uniform numerical minimum capital requirements began to surface. First, banks did not need to hold capital for off-balance sheet assets, though sizable losses could potentially stem from such exposures. Second, banks had plenty of opportunity for capital arbitrage, as on-balance sheet exposures required a fixed level of capital regardless of how risky the exposures were. Third, for multinational banks, different capital standards across jurisdictions led to competitive inequity concerns.

The second wave of changes in capital regulation As a result, the United States agreed to the Basel I international accord on capital adequacy standards in 1988, which tried to address the three concerns by introducing the concept of riskweighted assets, which allocated risk weights to different types of exposures (including off-balance exposures). Risk-weighted assets were used as the denominator in calculating minimum regulatory capital ratios 13 In 1990, the three federal regulatory

primary and total capital ratios of 6 percent, regional banks with assets over $\$ 1$ billion were subject to a minimum primary ratio of 5 percent and a total capital ratio of 6 percent, and the17 largest banks (the multinationals) did not have to adhere to preset numerical guidelines. The definition of the primary and total capital ratios changed over time. In 1985, primary capital consisted of stockholders' equity, perpetual preferred stock, loan loss reserves, and certain debt instruments that must be converted to common or preferred stock at maturity, while total capital consisted of primary capital plus secondary capital instruments such as limited-life preferred stock and certain qualifying debt instruments. These definitions were slightly different at the bank holding company level. The FDIC enforced a more stringent capital standard based on its own definition of adjusted capital to adjusted assets, which was unifrom across all state nonmember banks regardless of size. Vokey and Kearns (1985) provide a detailed description of the changes in capital regulation during the early 1980s.

${ }^{12}$ As a result, in 1985, all banks and BHCs had to maintain a primary capital ratio of 5.5 percent or more and a total capital ratio of at least 6 percent.

${ }^{13}$ Likewise, banks had to maintain a Tier 1 capital ratio of at least 4 percent and a total risk-based capital ratio of at least 8 percent by the end of 1992. Tier 1 capital consisted of common equity, some 
agencies then agreed upon a leverage ratio, defined simply as Tier 1 capital to average tangible assets, which was derived from the capital ratios used since the mid-1980s for regulatory purposes 14 According to Berger, Richard, Kashyap, Scalise, Gertler, and Friedman (1995), the leverage ratio was introduced to capture risks related to the leverage of banks not considered in the Basel I risk-based capital standards. The new rules stated that banks had to maintain a leverage ratio of at least 3 percent.

Finally, FDICIA, which was passed in 1991 and took effect in 1992, established five capital categories or thresholds for each of the three new regulatory capital ratios and had corresponding menus of mandatory and optional enforcement actions, otherwise known as Prompt Corrective Action, as the capital ratios declined ${ }^{15}$

\section{Data and Data Sources}

In this section, we discuss our explained and explanatory variables and their respective data sources.

Challenges in the construction of tangible capital ratios Our main explanatory variable is the change in capital positions of banks that lend in a given state. For identification, we require banks to choose their geographic markets randomly and to be immune to the developments in that market. Fortunately, the state-by-state deregulation of bank branching across state borders provides necessary exogenous variation.

Over our sample period, geographical restrictions on bank branching across state borders were removed on a state-by-state basis ${ }^{16}$ Because of the way deregulation

preferred stock, and minority interest in consolidated subsidiaries less goodwill, while Tier 2 capital consisted of loan loss reserves (limited to 1.25 percent of risk-weighted assets), subordinated debt (limited to 50 percent of Tier 1 capital), and other preferred convertible stock. The total risk-based capital ratio was defined as the sum of Tier 1 and Tier 2 capital relative to risk-weighted assets. For a more detailed definition, refer to Table A2.

${ }^{14}$ For a more detailed definition, refer to Table A2

${ }^{15}$ The adequate level of capital was defined as at least 5 percent of average assets for the leverage ratio, 6 percent of risk-weighted assets for the Tier 1 capital ratio, and 10 percent for the total risk-based capital ratio, each 2 percentage points above the respective minimums.

${ }^{16}$ As Goetz, Laeven, and Levine (2013) note, from the 1970s through the 1990s, individual U.S. states removed restrictions on the entry of out-of-state banks. Not only did states start deregulating in different years, but states also signed bilateral and multilateral reciprocal interstate banking agreements in a somewhat chaotic manner over time. There is enormous cross-state variation in the 20-year process of interstate bank deregulation, which culminated in the Riegle-Neal Interstate Banking and Branching Efficiency Act of 1995. 
unfolded, the resultant banking markets varied widely across states. While some banks headquartered in a given state established branches across state borders, other banks did not. While some markets had many branches of out-of-state banks, others did not. While the capital positions of smaller, in-state banks were likely affected by the developments in their states, the capital positions of larger, out-of-state banks that operated in host states were not. Therefore, for identification, for a given state, we need the main explanatory variable to emphasize changes in the capital positions of out-of-state banks that lend to firms in the host state rather than changes in the capital positions of in-state banks. This emphasis on larger banks with branches in multiple states is also desirable because the largest banks originate a very large fraction of all small business loans 17

We face two challenges in constructing our main explanatory variable. First, as capital regulation and capital reporting requirements changed over time, we need to construct a metric of capital positions that is consistent over time across banks. This metric is the tangible capital ratio. Second, because our unit of analysis is growth in employment (as well as growth in the number of firms and growth in the average size of firms) in a given industry in a given state, we need to aggregate these ratios across banks to a state level while strengthening the identification approach.

Time-consistent capital ratios at the bank level To address the first challenge, we proxy for banks' capital positions using tangible capital ratios, defined as the equity-to-assets ratio with intangible assets deducted from both the numerator and denominator. Prior to 1983 and the merger and acquisition wave in banking, we simply use the equity-to-assets ratio, as data for intangible assets are not available. Intangible assets were relatively modest during this early part of our sample, and expanding our capital ratio series back to 1976 allows our analysis to encompass periods prior to the introduction of minimum capital requirements of primary capital in 1981 for regional and community banks.18

Changes in the aggregated tangible capital ratio at U.S. commercial banks are plotted in Figure 1. Consistent with banks responding to stricter regulatory minimum

\footnotetext{
${ }^{17}$ For example, according to Call Reports, as of the second quarter of 2013, about one-third of all loans with original amounts of under $\$ 1$ million, a proxy for small business loans, were booked in the top five banks in terms of total assets. The data for loans with small original amounts begins in 2001.

${ }^{18}$ The M\&A wave in banking that accompanied bank deregulation resulted in substantial increases in goodwill on merged bank balance sheets.
} 
capital requirements both in the early 1980s and in the early 1990s, capital positions at banks improved from 1981 to 1987 and then again, with the exception of 1990, from 1989 to 1994. Consistent with Wall and Peterson (1987) and Wall and Peterson (1995), to the extent that these improvements in capital positions were likely driven by stricter capital requirements rather than by market discipline, changes in tangible capital ratios at the state level may provide a relatively exogenous measure for bank capital pressures that may be relatively removed from employment dynamics at a particular manufacturing industry in a particular state.

To tie in changes in tangible capital ratios more closely with changes in capital regulation, for a given bank, we regress a bank's tangible capital ratio on a set of bank-specific controls, which include total assets, reserves to loans, and others, and capital requirements, which include leads of required capital ratios. In the early part of our sample, when capital regulation was just being introduced in the United States, capital requirements were bank-type specific, as shown in Table 1. For example, in the early 1980s, capital requirements, set in terms of primary capital ratios, were higher for community banks than for multinational and regional banks. In the 1990s, capital requirements, set in terms of leverage (or adjusted capital) ratios, ceased to be bank-type specific and reached 5 percent for all three types. Our sample comes from Call Reports, spans the 1976-96 period, and includes more than 16500 banks of all three types. 19

We estimate the following regression model:

$$
\begin{aligned}
\text { CapRatio }_{b, t} & =\alpha_{b}+\rho_{1} \text { CapRatio }_{b, t-1}+\rho_{2} \text { CapRatio }_{b, t-2} \\
& +\phi_{A} \log \left(\text { Asset }_{b, t}\right)+\phi_{L R} \text { LoanRatio }_{b, t}+\phi_{R R} \text { ResRatio }_{b, t} \\
& +\nu_{P R} \text { PrimRatio }_{t}+\nu_{P R R R} \text { PrimRatio }_{t} \times \text { ResRatio }_{b, t} \\
& +\chi_{P R Q 2} \text { PrimRatio }_{b, t+2}+\chi_{P R Q 1} \text { PrimRatio }_{b, t+1}+\chi_{P R Q} \text { PrimRatio }_{b, t} \\
& +\psi_{L R Q 2} \text { LevRatio }_{t+2}+\psi_{L R Q 1} \text { LevRatio }_{t+1}+\psi_{L R Q} \text { LevRatio }_{t}+\epsilon_{b, t},
\end{aligned}
$$

where $b$ indexes bank and $t$ time; CapRatio $o_{b, t}$ is bank $b$ 's tangible capital ratio; $\alpha_{b}$ is bank b's fixed effect; Assets $_{b}$, LoanRatio $_{b}$, and ResRatio are bank b's total assets, loans to assets, and reserves to loans, respectively; PrimRatio is the dummy for the

\footnotetext{
${ }^{19}$ We excluded from our sample banks with no assets in the United States, no loans held in the United States, and no C\&I loans on the balance sheets.
} 
primary ratio regulatory regime; $\operatorname{PrimRatio}_{b}$ is the primary ratio requirement that is specific to bank $b$ (because of its type); and, finally, LevRatioQ is the leverage ratio requirement that is not specific to bank $b$. PrimRatio equals 1 when capital regulation was set in terms of the primary ratio. Because this regulatory regime relied on both capital and reserves ratios, we include the interaction term PrimRatio PresRatio $_{b, t}$ in the analysis.

The estimation results in Table 2 suggest that tangible capital ratios are persistent (coefficient $\rho_{1}$ is high) and that larger banks tend to have lower capital ratios than smaller banks (coefficient $\phi_{A}$ is negative). Other bank-specific variables appear to have no statistically significant effect on tangible capital ratios. In contrast, the capital regulation variables are all statistically significant. The results suggest that banks boosted their tangible capital ratios two years and one year ahead of the introduction of both the primary ratio requirement and the leverage requirement. They further boosted their tangible capital ratios in the years these requirements came into effect. Overall, the anticipation and implementation of the capital requirements appear to be significant determinants of tangible capital ratios at the bank level. Indeed, the inbetween variation is largely explained by the capital regulation variables, suggesting that capital regulation was a common driver of capital ratios across banks.

Tangible capital ratios at the state level To address the second challenge, we draw on Haltenhof, Lee, and Stebunovs (2014)'s methodology, which meets exogeneity requirements, to apportion bank-specific characteristics across banks to each U.S. state. Specifically, we aggregate tangible capital ratios, CapRatio $_{b, t}$, across banks for each state, CapRatio, , as follows:

$$
\operatorname{CapRatio}_{s, t}=\frac{\sum_{b \subset B} I_{b, s, t} w_{b, t} \text { CapRatio }_{b, t}}{\sum_{b \subset B} I_{b, s, t} w_{b, t}},
$$

where $B$ denotes a set of all banks; $b$ indexes bank, $s$ state, and $t$ time; $w_{b, t}$ is the balance of C\&I loan portfolio of bank $b$ at time $t$; and $I_{b, s, t}$ is an indicator of bank $b$ having branches in state $s{ }^{20}$ By construction, this aggregate tangible capital ratio puts more weight (because tangible capital ratios are weighted by the balances of C\&I loan portfolios) on larger, out-of-state banks that are immune to the developments

\footnotetext{
${ }^{20}$ Branches make loans, take deposits, and provide other services. In addition to branches, we consider loan production offices, which make loans but do not take deposits or provide other services. The results are not affected by inclusion of loan production offices into the definition of the indicator.
} 
in a given industry in a given state. In the regression analysis, we use a change in CapRatio $_{s, t}$ as the main explanatory variable to be consistent with the explained variables measured in growth rates.

In the appendix, to further support our identification approach, we use alternative definitions of CapRatio $_{s, t}$ and check the robustness of the results to these alternatives. First, we exclude the largest states in the country from the sample - an exclusion that puts even more weight on changes in the capital positions of out-of-state banks that lend to firms in a given smaller state. Second, we construct state-level tangible capital ratios that use certain weights that capture banks' geographical footprint and intensity rather than deregulation indicators. Finally, to tie in changes in tangible capital ratios more closely with changes in capital regulation, we apply the methodology to aggregate tangible capital ratios that are predicted by Equation 1 conditional on capital regulation parameters and some bank specifics.

In our empirical work, we rely more on the tangible capital ratios and less on the predicted tangible capital ratios for a couple of reasons. First, banks anticipated the introduction of such regulation and might have timed their balance sheet adjustments accordingly. While we do model such anticipatory capital actions, the reality might be more complex than the model. Second, banks might have been given different grace periods to meet the newly introduced capital requirements. We believe that addressing these factors in full detail requires an unnecessarily complicated analysis. And we note that the results for the predicted tangible capital ratios are qualitatively similar to those for the tangible capital ratios projected over the same sample period (as shown in Table A1 in the appendix). After all, the tangible capital ratio reflects capital requirements, supervisory actions, and other factors.

We emphasize that our measure of state-level capital ratios - which are, on average, heavily influenced by bank operations in other states, nationally, or internationallyprovide sufficient exogenous variation in capital ratios that are not affected by economic conditions in a given state. For example, the mean percentage of loans held in domestic offices at commercial banks that have a branch outside a particular state is 45.65 percent (with a standard deviation of 27.57 percent) from 1974 to 1996.

Employment, the number of firms, and the average size of firms Our explained variables are from the County Business Patterns (CBP), which is an annual survey conducted by the Census Bureau. As noted by Cetorelli and Strahan (2006), 
the survey gives "the best way to consider industry structure over a long span of time at a disaggregated level." The survey provides data on employment and the number of establishments by establishment-size class in mid-March of each year at a industry-state level. For example, the survey gives employment, the number of establishments, and the number of establishments by establishment size in 1997 in Alabama in Textile mill products industries. More generally, the CBP data show that, in 1997, all industries employed 101 people in 6.8 million establishments. Over half of these establishments had fewer than 10 employees, and more than 98 percent of establishments had fewer than 500 employees. As in Cetorelli and Strahan (2006), for a given industry in a given state, we derive the average size of establishments, measured in employees, as the ratio of employment and the number of establishments.

We note that an establishment in the context of the data is an economic unit that employs workers and produces goods and services, such as a plant, a factory, or a restaurant that employs people, and may not correspond to a firm. 212 However, as in the literature, we use firms and establishments interchangeably, with evidence that the number of firms and the number of establishments are highly correlated and that firms make up the majority of establishments. For example, Black and Strahan (2002) note that the rate of the creation of new businesses is correlated with the share of new establishments in a local economy, while Davis, Haltiwanger, Jarmin, and Miranda (2006) show that, though each publicly traded firm operates about 90 establishments on average, there are only 1.16 establishments per privately held firm.

While the data are available for a very long period and for a large number of industries, we focus on manufacturing industries over the 1977-97 period. This period encompasses the two waves of changes in regulatory capital adequacy standards in the United States, where the changes in banks' capital positions over the period likely reflected the changes in bank capital regulation.

As in Cetorelli and Strahan (2006) and others, we study manufacturing industries for two reasons. First, firms in these industries do not generate cash flows sufficient to cover their capital and other expenditures because of technologies they use. Therefore, they tend to borrow in capital and bank loan markets. Second, these industries have had a relatively stable structure over time. As the CBP suggests, both small and large firms have been operating in these industries for a long time ${ }^{22}$ While large

\footnotetext{
${ }^{21}$ A firm may have multiple establishments.

${ }^{22}$ Other industries may not be suitable for our purposes of consolidation trends. For example, in retail industries, the share of activity accounted for single-establishment firms fell from 60 percent
} 
firms may have access to national capital and bank loan markets, small firms may not and, therefore, may rely on local bank markets and other local sources to raise funding.

As in Cetorelli and Strahan (2006), among 20 manufacturing industries at a twodigit SIC level, we identify 10 industries that depend on external finance more than the others. This distinction is based on Rajan and Zingales (1998)'s measures of dependence on external finance for mature firms because their financial decisions likely reflect technological rather than financial constraints. ${ }^{23}$ The measures are calculated as the fraction of total capital expenditures not financed by internal cash flows from operations using the Compustat data for large, mature firms over the 1980-97 period.

Each industry is then classified as either dependent on external finance or not dependent based on whether its Rajan-Zingales measure lies above or below the median of the Rajan-Zingales measures. The 10 manufacturing industries (along with their two-digit SIC codes) that depend on external finance are the following: Chemicals and allied products (28), Electrical and electronic equipment (36), Textile mill products (22), Petroleum and coal products (29), Paper and allied products (26), Rubber and plastic products (30), Lumber and wood products (24), Primary metal industries (33), Industrial machinery and equipment (35), and Transportation and equipment (37). The industries that do not depend on external finance are the following: Instruments and related products (38), Printing and publishing (27), Miscellaneous manufacturing (39), Stone, clay, glass, and concrete products (32), Furniture and fixtures (25), Fabricated metal products (34), Food and kindred products (20), Apparel and other textiles (23), Tobacco manufactures (21), and Leather and leather products (31). As the CBP suggests, in 1997, manufacturing industries that depend on external finance employed 7.7 million people in 208,000 establishments and manufacturing industries that do not depend on external finance employed 9.5 million people in 175,000 establishments.

Following the literature, we associate dependence on external sources of finance with dependence on bank loans ${ }^{24}$ Although, in aggregate, U.S. firms' dependence on bank loans may be somewhat limited, the dependence is nevertheless larger for some

in 1967 to just 39 percent in 1997; see Jarmin, Klimek, and Miranda (2009) for details.

${ }^{23}$ The measures are widely viewed as technologically determined industry characteristics that are innate to the manufacturing processes and exogenous from the perspective of individual firms.

${ }^{24}$ In the Rajan-Zingales context, whether gaps in financing of physical capital investment are met with bank or market funding is irrelevant. Moreover, for many large firms, the degree of dependence on bank loans cannot be reliably estimated using Compustat data. 
firms (such as relatively small, privately held firms) than for others (such as large publicly traded firms) ${ }^{25}$ Using a more direct measure to capture dependence on bank loans would subject our analysis to endogeneity concerns, as a given industry's low dependence on bank loans could simply indicate financing constraints.

As in the literature, implicit in our identification strategy is the assumption that dependence on external financial is constant over time, or, rather, that the industry ordering (in terms of dependence on external finance) does not change over time. Indeed, as Haltenhof, Lee, and Stebunovs (2014) show, the Rajan-Zingales measures for mature firms change somewhat over time, but the industry ordering remains relatively stable. That is, the industries that are identified as more dependent on external finance remain generally the same whether the 1980s data or more recent data are used.

Over the sample period, a variety of factors might have affected employment growth; more limited access to bank loans resulting from new capital regulation might be just one of them. Nevertheless, Figure 2, which shows growth rates of employment by industry type for the entire country, highlights a potential link between capital regulation and the real sector. While employment growth in both types of industries tends to decline ahead of new capital regulation becoming effective and for some time after that, growth in employment in industries that depend on external finance tends to decline more. And because of the confounding factors, we have to rely on the differential effects of bank capital pressures on employment in industries that depend and do not depend on external finance.

\section{Empirical Strategy and Data Summary}

In this section, we describe the empirical strategy, regression models, and data to estimate the effect of bank capital pressures on employment, the number of firms, and the average size of firms.

Historically, commercial banks increase their capital ratios by tightening lending standards and terms and, therefore, limiting the supply of bank loans. And a tightening of access to bank loans may have significant real effects, in part because of the

\footnotetext{
${ }^{25} \mathrm{As}$ Haltenhof, Lee, and Stebunovs $(2014)$ point out, for firms with less than $\$ 25$ million in total assets, the ratio of bank loans to total liabilities is more than 20 percent, while that for firms with more than $\$ 25$ million in total assets is less than 10 percent. These are averages calculated using the Census' Quarterly Finance Review data over the 2000-07 period.
} 
lack of substitutes for bank loans. Such effects may be particularly strong for firms in industries that depend on external sources of finance and, in these industries, for smaller firms that may not have access to national capital and bank loan markets. In other words, the magnitude of the effects of bank capital pressures on employment and firm dynamics depends on the degree of substitutability of bank loans for nonbank funds: The lower the degree the larger the effects. ${ }^{26}$

We choose to focus on manufacturing industries over the late 1970s to the mid1990s period for a few reasons. First, the dependence of these industries on external sources of finance, particularly on bank loans, has been well documented in the literature. The variation in dependence on external finance across manufacturing industries helps to address potential omitted variable bias. Second, these industries have had relatively stable structures over the last decades, with both small and large firms operating side by side. The variation in dependence on external finance for firms of different sizes within the same industry helps to identify the effects that we are after. While larger firms have access to national capital and bank loan markets, smaller firms tend to borrow from local banks. Third, the Census Bureau makes disaggregated data available for these industries at a state level over a long period. Finally, over our sample period, the randomized presence of out-of-state banks provides exogenous variation in bank capital pressures in the in-state markets.

Manufacturing industries tend to produce goods tradable across state borders; demand for these goods is more likely to be affected by national factors and less likely by home-state factors. Therefore, by controlling for national industry-specific demand for these goods, we can control for industry-specific demand for finance and other factors no matter the state.

\subsection{Empirical Strategy}

Econometric strategy We exploit the cross-state, cross-time variation in bank tangible capital ratios - brought about by bank branch deregulation on a state-bystate basis - to identify the real effects of bank capital pressures. We use state-level tangible capital ratios that are heavily influenced by banks with branch operations

\footnotetext{
${ }^{26}$ The degree of the substitutability of loans from one bank with loans from another bank likely matters too. This degree may be somewhat low for small, opaque borrowers because of asymmetric information - a situation that necessitates developing relationships between lenders and borrowers. Our data are not detailed enough to identify the importance of the bank loan-to-bank loan substitutability.
} 
in multiple states and other countries and we think of changes in these ratios as exogenous shifters in financing conditions. Our approach is similar in spirit to that of a few other studies. Peek and Rosengren (2000) use the Japanese banking crisis to test whether a loan supply shock to branches and agencies of Japanese banks affected construction activity in the U.S. commercial real estate market. Garmaise and Moskowitz (2006) use a similar argument to address possible reverse causality by studying the effects of changes in large bank mergers on changes in crime at the metropolitan statistical area level, arguing that such merger activity instruments for changes in bank competition at the local level.

We investigate how bank capital pressures affect growth in employment, the number of firms, and the average size of firms. Casting regressions in growth rates allows us to control for trends in these variables 27

We estimate variations of two regression models: One includes a broad set of explanatory variables and some fixed effects, and the other a smaller set of explanatory variables and a broader set of fixed effects. The latter regression model is our main model because it allows us to control for many observed variables and demand-side factors. In both models, we lag some explanatory variables one year to capture delayed adjustments in employment and firm dynamics to changes in those explanatory variables.

\footnotetext{
${ }^{27}$ These variables are highly persistent in levels - the data property which requires complex dynamic models. In contrast, the growth rates of the explained variables are not persistent, with very low autoregressive coefficients. In support of this point, we present in the appendix the estimation results of a model for employment with an autoregressive term included. The quantitatively similar results suggest that lagged dependent variables can be omitted from our regression models.
} 
The first regression model - our baseline model — is the following:

$$
\begin{aligned}
\Delta Y_{i, s, t} & =\alpha_{i, s} \\
& +\beta_{C R} \text { External }_{i} \times \Delta \text { CapRatio }_{s, t-1} \\
& +\theta_{C R} \Delta \text { CapRatio }_{s, t-1} \\
& +\beta_{R R} \text { External }_{i} \times \Delta \text { ResRatio }_{s, t-1} \\
& +\theta_{R R} \Delta \text { ResRatio }_{s, t-1} \\
& +\beta_{H H I} \text { External }_{i} \times \Delta H H I_{s, t-1} \\
& +\theta_{H H I} \Delta \text { HHI }_{s, t-1} \\
& +\beta_{\text {Inter }} \text { External }_{i} \times \text { Interstate }_{s, t-1} \\
& +\theta_{\text {Inter }_{\text {Interstate }}, t-1} \\
& +\beta_{\text {Intra } \text { External }_{i} \times \text { Intrastate }_{s, t-1}} \\
& +\theta_{\text {Intra }_{\text {Intrastate }}, t-1} \\
& +\phi \text { RGSP }_{s, t-1} \\
& +\gamma_{i, t}+\epsilon_{i, s, t},
\end{aligned}
$$

where $i$ indexes the industry, $s$ the state, and $t$ the time; $\Delta Y_{i, s, t}$ is the growth rate of either employment, the number of firms, or the average size of firms in industry $i$; $\alpha_{s, i}$ is the industry-state fixed effect, which controls for industry-state-specific trends and for self-selected locations of industries across states; External $_{i}$ is the RajanZingales indicator for the dependence of industry $i$ on external finance; CapRatio ${ }_{s, t}$ is the tangible capital ratio for banks that have branches in state $s$; ResRatio R $_{s, t}$ is the reserves-to-loans ratio for banks that have branches in state $s ; H H I_{s, t}$ is the deposit-based Herfindahl-Hirschman Index for state $s$; Interstate Int, $_{\text {and }}$ Intrastate I $_{s, t}$ are the indicators for state $s$ removing interstate and intrastate branching restrictions, respectively; and $R G S P_{s, t}$ is the real gross state product for state $s$-a basic control for local demand ${ }^{28} \epsilon_{j, s, t}$ is the error term that is robust to heteroskedasticity.

We emphasize that we include industry-year fixed effects, $\gamma_{i, t}$, to control for national, industry-specific conditions. These fixed effects are particularly important because they control for the stage of the credit and business cycles (and other factors) that are specific to each industry. Because manufacturing industries produce

\footnotetext{
${ }^{28}$ Note that the reserves-to-loans ratio at a state level, ResRatio ${ }_{s, t}$, is constructed similarly to the tangible capital ratio at a state level, CapRatio,$t_{s}$.
} 
goods that are tradable across state borders - that is, the markets for these goods tend to be national rather than local-firms in the same industry but in different states face similar demand-side factors (if not supply-side factors, too). Including these industry-year fixed effects helps us control for demand for loans and to rule out a story that a fall in demand for manufacturing goods increases bank capital pressures and decreases employment in manufacturing industries ${ }^{29}$

The second regression model-our main model - is the following:

$$
\begin{aligned}
\Delta Y_{i, s, t} & =\alpha_{i, s} \\
& +\beta_{C R} \text { External }_{i} \times \Delta \text { CapRatio }_{s, t-1} \\
& +\beta_{R R} \text { External }_{i} \times \Delta \text { ResRatio }_{s, t-1} \\
& +\beta_{H H I} \text { External }_{i} \times \Delta \text { HHI }_{s, t-1} \\
& +\beta_{\text {Inter }} \text { External }_{i} \times \text { Interstate }_{s, t-1} \\
& +\beta_{\text {Intra }} \text { External }_{i} \times \text { Intrastate }_{s, t-1} \\
& +\gamma_{i, t}+\delta_{s, t}+\epsilon_{i, s, t},
\end{aligned}
$$

where we use the earlier notation. In this model, while we use a smaller set of explanatory variables, we broaden a set of fixed effects. We include $\delta_{s, t}$, which is the state-year fixed effect that controls for local demand and other local conditions. This additional fixed effect is not industry-specific, but this is not a limitation. The regression model already includes the industry-year fixed effect, $\gamma_{i, t}$, which, given that the market for manufacturing goods is likely national, is a sufficient industry- and time-specific control. $\epsilon_{j, s, t}$ is the error term that is robust to heteroskedasticity.

We believe that the main model offers the strongest specification that we can have. In this model, we have exogenous variation in the main explanatory variable (changes in the tangible capital ratio at a state level); controls for omitted variable bias; and controls for unobserved, time-varying factors that affect employment and firm dynamics at both industry and state levels. In other words, the main model allows us to identify the effects of bank capital pressures on employment and firm dynamics cleanly.

In both models, the effects are captured by the the coefficients $\beta_{C R^{\mathrm{S}}}$ on the in-

\footnotetext{
${ }^{29}$ The Interstate Banking and Branching Efficiency Act (IBBEA) permitted unrestricted interstate banking in 1995 and interstate branching in 1997. These effects are subsumed in our industry-year fixed effects, as they were implemented nationally at once.
} 
teraction term of External Ex $_{i}$ anRatio Capt-1 $_{s}$. One may expect these coefficients of interest to be negative for growth in employment, the number of firms, and the average size of firms. One may also expect these coefficients to be larger in magnitude at a higher statistical significance for growth in employment and firm dynamics for smaller firms. We note, though, that there are some a priori reasons that the number of firms may not necessarily decline with stronger bank capital pressures.

Data Summary Our sample of industry-state-year observations spans 21 years from 1977 to 1997 and includes 668 industry-state groups with 13360 observations. The summary statistics in Table 3 shows that, in terms of growth rates of employment, the number of firms, and the average firm size at an industry-state level, manufacturing industries that depend on external finance and those that do not were very similar. Over the sample period, employment in the two types of industries grew by 1 percent a year, with the number of firms growing and the average size of firms shrinking 30 Figure 3 illustrates variation in growth in employment across industries, states, and time. Employment growth at the 10th, 50th, and 90th percentiles tended to slow down around the periods of tightening capital regulation-similarly to the aggregate employment growth in Figure 2 .

Our sample period includes two waves of changes in bank capital regulation and waves of interstate and intrastate bank branching deregulation. The summary statistics in Table 4 show that tangible capital and reserves-to-loans ratios grew modestly, on average, over the sample period. The deposit-based concentration index suggests that the concentration in local banking markets increased, on average 31 The states' economies, on average, expanded at a rate of about 3 percent a year. Note that since we use lagged explanatory variables, we consider the sample of state-level bank balance sheet measures from 1976 to 1996, which includes measures for all 50 states and the District of Columbia. Figure 4 illustrates variation in state-level tangible capital ratios across states and time. State-level tangible capital ratios at the 10th, 50th, and 90th percentiles tended to increase around the two waves of changes in bank capital regulation - similarly to the aggregate tangible capital ratio in Figure 1.

\footnotetext{
${ }^{30}$ While in terms of growth rates the two types of industries are similar, in terms of levels they are different. Industries that depend on external finance employ more employees, have fewer firms, and have, on average, larger firms than industries that do not depend on external finance.

${ }^{31}$ The Herfindahl-Hirschman Index is the sum of squared local market commercial bank deposit shares. As data on the CBP data are as of March, we use a year and three quarters lagged HerfindahlHirschman indexes since the Summary of Deposits data are as of June in a given year.
} 


\section{Estimation Results}

In this section, we present results for the two models estimated on the full sample and for the main model estimated over several subsets of the full sample. As a reminder, we associate changes in CapRatio $_{s, t}$ with changes in bank capital pressures, which are, to a large extent, driven by capital regulation and supervisory demands. Note that the subsequent tables are structured similarly. Each table has three columns: The results for growth in employment are shown in column (1), for the number of firms in column (2), and for the average size of firms in column (3). In the tables, the primary variables of interest are the interaction terms because they help identify the differential effect of the explanatory variables on employment and firm dynamics in industries that depend on external finance.

The results for the full sample First, we analyze the results for the two models estimated on the full sample. Table 5 presents the results for the baseline model (given by Equation 3), that is, the model that includes a broad set of explanatory variables and some fixed effects. As the first row shows, an increase in the change in statelevel tangible capital ratio of 1 percentage point reduces growth in employment by about 0.6 percentage point and growth in the average size of firms by 0.8 percentage point. In contrast, an increase in bank capital pressures does not have a statistically significant effect on growth in the number of firms.

The lack of evidence that a worsening in access to bank credit has an effect on the number of firms appears to be consistent with the literature. For example, Haltenhof, Lee, and Stebunovs (2014) find that a tightening of C\&I lending standards - another metric capturing a worsening in access to bank credit - does not have a statistically significant effect on growth in the number of firms. In addition, Black and Strahan (2002) find that an increase in bank concentration is associated with slower growth in the number of firms.

There are several reasons why there may be no statistically significant relationship between bank capital pressures and the number of firms. And these reasons may differ for small and large firms. For small firms, decisions by entrepreneurs to incorporate a business may depend less on the availability of bank credit (as setting up a firm is not costly) and more on local economic conditions (such as local demand) ${ }^{32}$ In

\footnotetext{
${ }^{32}$ Indeed, according to Djankov, Porta, Lopez-De-Silanes, and Shleifer (2002), entrepreneurs' av-
} 
addition, layoffs by firms that are induced by a worsening in access to credit may spur the creation of firms, which may boost the number of firms in times of economic distress ${ }^{33}$ As for large firms, consistent with the "hysteresis" behavior modeled in other strands of the literature, it may be that, following a tightening of access to credit (an unfavorable shock), the sunk-cost aspect of the firm entry decision in the presence of fixed per-period costs results in these firms continuing to serve the market, but perhaps at a smaller scale that requires fewer employees ${ }^{34}$ In our data, while the smallest establishments employ a relatively small fraction of employees in manufacturing industries, the first reason is more likely to apply. In addition, because these small firms are numerous, they may introduce noise into the aggregate series.

Table 6 presents the results for the main model (given by Equation 3) - that is, the model that includes a small set of explanatory variables and a broad set of fixed effects. While this regression model is better for identification (because it allows us to control for many observed variables and state- and industry-specific demand-side factors), the estimation results are quantitatively similar to those in Table 5. The similarity suggests that, while the state-year fixed effects have some explanatory power, they are not as important as the industry-year fixed effects in explaining employment and firm dynamics. In a subsequent section, we check the robustness of our results to alternative definitions of tangible capital ratios at the state level.

\section{The results for the sample of states with a smaller share of community}

banks Second, we present the results for the main model estimated on a sample of state-years with a smaller share of community banks 35 We reason that omitting from the analysis states in which banking markets are dominated by community banks strengthens the identification approach. This holds because changes in tangible capital ratios in the remaining states will reflect changes in capital positions of out-

erage cost of starting a firm was 1.7 percent of per capita income in the United States in 1999, or $\$ 520$.

${ }^{33}$ For example, Aaronson, Rissman, and Sullivan (2004) document the increase in the number of firms, which was accompanied by a fall in employment at the aggregate level.

${ }^{34}$ This argument is drawn from Alessandria and Choi (2007) in the international trade literature.

${ }^{35}$ These results are only for state-year combinations where the share of local deposits supplied by community banks is smaller than 80 percent. This exclusion resulted in about a 25 percent loss in the number of state-year observations. While the 80 percent threshold may appear to be high, we note that larger, out-of-state banks tend to have smaller deposit shares in the host states' local markets because, in contrast to community banks, these banks tend to borrow significant amounts in capital markets. We also note that, in terms of loan volumes, larger banks, rather than small, local lenders, tend to supply the bulk of C\&I loans. 
of-state banks, which are likely to be immune to the economic conditions in the host states ${ }^{36}$ Indeed, the results in Table 7 are stronger in terms of magnitude and statistical significance than those in Tables 5 and 6 . As the first row shows, an increase in a change in state-level tangible capital ratio of 1 percentage point reduces growth in employment by nearly 0.8 percentage point and growth in the average size of firms by about 0.9 percentage point. In the appendix, we analyze another way of strengthening the identification approach where we exclude the largest three states from the sample. Such an exclusion puts more weight on changes in the capital positions of out-of-state banks in construction of changes in state-level tangible capital ratios.

The results for the samples of small and large firms Third, we show the results for the main model estimated on a sample of small firms (with fewer than 99 employees) and on a sample of large firms (with more than 99 but fewer than 500 employees). These regressions highlight that the degree of the substitutability of loans for other nonbank credit matter for the identification of the effect of bank capital pressures on employment and firm dynamics. While larger firms have access to national capital and bank loan markets, smaller firms tend to borrow locally and, therefore, are at the mercy of local lenders. Indeed, as a comparison of the results in Tables 8 and 9 reveals, an increase in a change in state-level tangible capital ratio of 1 percentage point reduces growth in employment in small firms by about 0.8 percentage point, but has no effect on large firms' employment and firm dynamics 37

\section{The results for the samples of small firms in states with a smaller share of} community banks Finally, we provide the results for the main model estimated on a sample of smaller firms in states with a smaller share of community banks. We believe that this sample strengthens the identification approach the most. On the one hand, changes in tangible capital ratios in these states reflect changes in capital

\footnotetext{
${ }^{36}$ Community banks tend to be small and undiversified. They tend to supply deposits and make loans locally and, therefore, their capital positions are more likely to be affected the local economic conditions.

${ }^{37}$ When there are missing values allotted to the number of employees due to confidentiality issues in the CBP data, we simply take the midpoint of the range of employees in a particular establishment bucket and multiply that by the number of establishments in the bucket to get total employment for that class of establishments. For example, if there are 2 establishments in the 100 to 249-employee bucket, the total number of employees will be assumed to be 349 for that particular bucket for a given state. Regression results for establishments with 500 or more employees also show no effect on employment dynamics, but much more of the data have missing values due to data confidentiality issues. These results are, therefore, not shown.
} 
positions of out-of-state banks that are likely to be immune to the economic conditions in the host states. On the other hand, changes in tangible capital ratios likely affect growth in small firm employment more than in large firms. The results in Table 10 are quantitatively similar to those in the earlier tables, hence lending credibility to the earlier specifications.

Robustness checks While focusing on employment, we conduct several robustness checks, results of which are presented in the appendix. First, we estimate the main model with a lagged dependent term included. As expected, growth in employment exhibits little persistence, so the propagation mechanism from a one-time capital shock is weak. Second, we exclude the largest three states from the sample and estimate the main model. For the remaining states, this exclusion puts more weight on changes in the capital positions of out-of-state banks that lend to firms in a given smaller state. Third, to tie changes in tangible capital ratios more closely to changes in capital regulation, we aggregate tangible capital ratios that are predicted by Equation 1 conditional on capital regulation parameters and bank specifics and then use those predicted tangible capital ratios as the main explanatory variable in the main model.

Finally, we estimate the main model with alternative state-level tangible capital ratios, which rely on more complex metrics of banks' geographical footprint and capture the intensity of a given bank's presence in a given geographical market. For these alternatives, we draw again on Haltenhof, Lee, and Stebunovs (2014)'s methodology to apportion bank-specific characteristics across banks to each U.S. state that meets exogeneity requirements. Specifically, in Equation 2, we replace the balance of the C\&I loan portfolio of bank $b, w_{b, t}$, and the indicator of bank $b$ having branches in state $s, I_{b, s, t}$, with either the number of branches of bank $b$ in state $s$ or the amount of deposits bank $b$ supplied through its branches in state $s$. While the former metric proxies the intensity in local lending with the number of branches, the latter metric equates banks' local lending with local deposits.38 Indeed, close linkages between deposit taking and loan making at the local level is supported, to a significant extent, by the Community Reinvestment Act (CRA) of 1977. Because of the act, a significant share of deposits supplied in a given location should be lent out in the same location 39 As shown in Table 11 for the first alternative and Table 12 for the second

\footnotetext{
${ }^{38}$ In the banking literature, the deposit footprint has been used as a proxy for the loan footprint as well. For example, Peek and Rosengren (1995) use deposits as a proxy for loans.

${ }^{39}$ The CRA is intended to encourage depository institutions to help meet the credit needs of
} 
alternative, the results are not affected by modifying the state-level tangible capital ratios to reflect the intensity of banks' geographical footprint.

In our empirical work, we rely more on the state-level tangible capital ratio defined in Equation 2 than on its two alternatives. The former metric is, in a way, a marginal concept because, by construction, it can emphasize changes in capital positions of large out-of-state banks operating in the host states. In contrast, the alternative metric based on the numbers of branches is, in a way, an average concept because it emphasize bank capital pressures with a large presence in the host states. Finally, the alternative metric based on the amounts of local deposits equates local deposit taking with local loan making, an assumption that does not necessarily hold in practice.

\section{Conclusions}

We exploit exogenous variation in state-level tangible capital ratios (caused by bank branch deregulation on a state-by-state basis) to identify the effects of bank capital pressures on employment and firm dynamics in manufacturing industries that depend on external finance. Our results show that stronger capital pressures, manifested through increasing tangible capital ratios due, in part, to stricter capital regulation, result in a slowdown in growth in employment and the average size of firms but have no effect on growth in the number of firms. Such effects were particularly strong for smaller firms that might not have had access to national capital and bank loan markets. Our findings indicate that a tightening of capital requirements may have significant real effects, in part because of the lack of substitutes for bank loans.

Our estimate of the effects of capital pressures on nonfinancial employment and firm dynamics may have implications for the labor market in the current economic environment. For example, the greater anticipated regulatory burden faced by commercial banks may temporarily hold back employment growth in manufacturing industries that depend on external finance, thus contributing to broader weak labormarket conditions. In the longer term, the displaced workers in these industries may be absorbed by firms in other industries, as our results do not suggest permanent impediments to growth 40

communities in which they operate, including low- and moderate-income neighborhoods and to small businesses, consistent with safe and sound operations.

${ }^{40}$ Although the results imply that changes in capital regulation may permanently tilt the composition of employment across industries - for example, from manufacturing to other industries in the 
We note, though, that our analysis is based on the economic and regulatory environment of the 1980s and 1990s and, therefore, has limitations for understanding the current environment. Over the last two decades, a rise of nonbank financing - for example, loans and leases from captive finance companies - may mitigate some of the effects that we found based on historical data. And because of technological advances, some of the effects on employment in aggregate may be less pronounced, as displaced workers may be less restricted in searching for new jobs or starting up businesses. Finally, though the degree of regulatory tightening may be stronger than in the past, banks that have historically held substantial buffers of capital above the required minimums may also choose to hold smaller excess capital buffers. This change may mitigate some of the effects on the real sector. In terms of the implementation of the new Basel III capital requirements, regulators have been careful to allow sufficient time - about five years - to increase capital ratios in the hope that banks will achieve higher capital ratios through retention of earnings rather shrinkage of assets. Such accommodation gives banks more time than they were given during the two previous waves of changes in regulatory capital regimes.

economy - we do not consider such inter-sector movements in our analysis. 


\section{References}

Aaronson, D., E. R. Rissman, and D. G. Sullivan (2004): "Assessing the Jobless Recovery," Federal Reserve Bank of Chicago Economic Perspectives, 28(2), $2-20$.

Aiyar, S., C. W. Calomiris, and T. Wieladek (2014): "Does Macro-Pru Leak: Evidence from a UK Policy Experiment," Journal of Money, Credit and Banking, 46(S1), 181-214.

Alessandria, G., And H. Choi (2007): "Do Sunk Costs of Exporting Matter for Net Export Dynamics?," Quarterly Journal of Economics, 122(1), 289-336.

Benmelech, E., N. K. Bergman, and A. Seru (2011): "Financing Labor," NBER Working Papers 17144, National Bureau of Economic Research, Inc.

Berger, A. N., Richard, A. K. Kashyap, J. M. Scalise, M. Gertler, and B. M. Friedman (1995): "The Transformation of the U.S. Banking Industry: What a Long, Strange Trip It's Been," Brookings Papers on Economic Activity, 1995(2), 55-218.

Black, S. E., and P. E. Strahan (2002): "Entrepreneurship and Bank Credit Availability," Journal of Finance, 57(6), 2807-2833.

Cetorelli, N. (2004): "Real Effects of Bank Competition," Journal of Money, Credit and Banking, 36(3), 543-558.

Cetorelli, N., and P. E. Strahan (2006): "Finance as a Barrier to Entry: Bank Competition and Industry Structure in Local U.S. Markets," Journal of Finance, 61(1), 437-461.

Davis, S. J., J. Haltiwanger, R. Jarmin, and J. Miranda (2006): "Volatility and Dispersion in Business Growth Rates: Publicly Traded versus Privately Held Firms," NBER Working Paper No. 12354.

Djankov, S., R. L. Porta, F. Lopez-De-Silanes, and A. Shleifer (2002): "The Regulation of Entry," Quarterly Journal of Economics, 117(1), 1-37. 
Garmaise, M. J., and T. J. Moskowitz (2006): "Bank Mergers and Crime: The Real and Social Effects of Credit Market Competition," Journal of Finance, 61(2), 495-539.

Goetz, M. R., L. Laeven, and R. Levine (2013): "Identifying the Valuation Effects and Agency Costs of Corporate Diversification: Evidence from the Geographic Diversification of U.S. Banks," pp. 1787-1823.

Haltenhof, S., S. J. Lee, and V. Stebunovs (2014): "The Credit Crunch and Fall in Employment during the Great Recession," Journal of Economic Dynamics and Control, 43, 31-57.

Hancock, D., And J. A. Wilcox (1998): "The "Credit Crunch" and the Availability of Credit to Small Business," Journal of Banking and Finance, 22, 983-1014.

Jarmin, R. S., S. D. Klimek, and J. Miranda (2009): "The Role of Retail Chains: National, Regional and Industry Results," in Producer Dynamics: New Evidence from Micro Data, ed. by T. Dunne, J. B. Jensen, and M. J. Roberts, pp. 237-262. University of Chicago Press.

Kashyap, A. K., J. C. Stein, and S. Hanson (2010): "An Analysis of the Impact of "Substantially Heightened" Capital Requirements on Large Financial Institutions," Working paper.

Keeley, M. C. (1988): "Bank Capital Regulation in the 1980s: Effective or Ineffective?," Federal Reserve Bank of San Francisco Economic Review, (1), 3-20.

Kiley, M. T., And J. Sim (2011): "Financial Capital and the Macroeconomy: A Quantitative Framework," FEDS Working Paper No. 2011-27.

Lown, C. S., And D. P. Morgan (2006): "The Credit Cycle and the Business Cycle: New Findings Using the Loan Officer Opinion Survey," Journal of Money, Credit, and Banking, 38(6), 1575-97.

Myers, S. C., And N. S. Majluf (1984): "Corporate Financing and Investment Decisions When Firms Have Information That Investors Do Not," Journal of Financial Economics, 13(2), 187-221. 
Nickell, S. (1981): "Biases in Dynamic Models with Fixed Effects," Econometrica, 49(6), 1417-1426.

Peek, J., And E. S. Rosengren (1995): "The Capital Crunch: Neither a Borrower nor a Lender Be," Journal of Money, Credit and Banking, 27(3), 625-638.

(2000): "Collateral Damage: Effects of the Japanese Bank Crisis on Real Activity in the United States," American Economic Review, 90(1), 30-45.

Rajan, R., And L. Zingales (1998): "Financial Dependence and Growth," American Economic Review, 88(3), 559-86.

Rice, T., and P. E. Strahan (2010): "Does Credit Competition Affect Small-Firm Finance?," Journal of Finance, 65(3), 861-89.

Vokey, R. S., And K. L. Kearns (1985): "Issues in Capital Adequacy Regulation," The Bankers Magazine, 168, 35-43.

Wall, L. D., And D. R. Peterson (1987): "The Effect of Capital Adequacy Guidelines on Large Bank Holding Companies," Journal of Banking and Finance, $11,581-600$.

(1995): "Bank Holding Company Targets in the Early 1990s: The Regulators versus the Markets," Journal of Banking and Finance, 19, 563-74. 
Figure 1: Changes in Tangible Capital Ratios

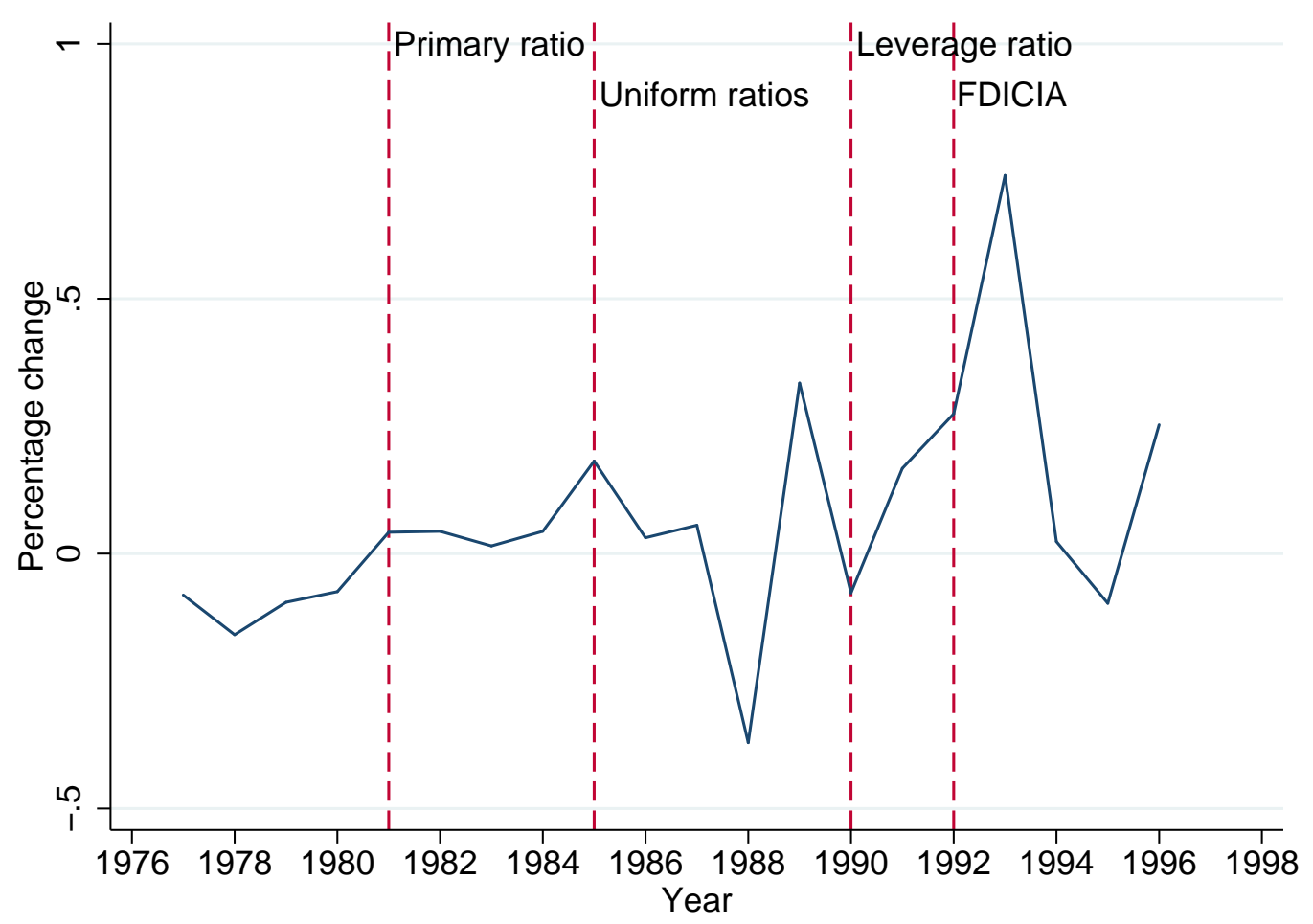

Notes: The aggregate tangible capital ratio is defined as the aggregate equity-to-assets ratio at U.S. commercial banks, with deductions for intangible assets in both the numerator and denominator when intangible assets are available. Data for intangible assets became available in 1983. Minimum capital requirements for the primary capital ratio were introduced in 1981 for community and regional banks. By 1985, uniform minimum requirements were applied to all types of banks. The leverage ratio was introduced in 1990, and FDICIA was implemented in 1992 for all banks. Source: Call Reports. 
Figure 2: Employment Growth

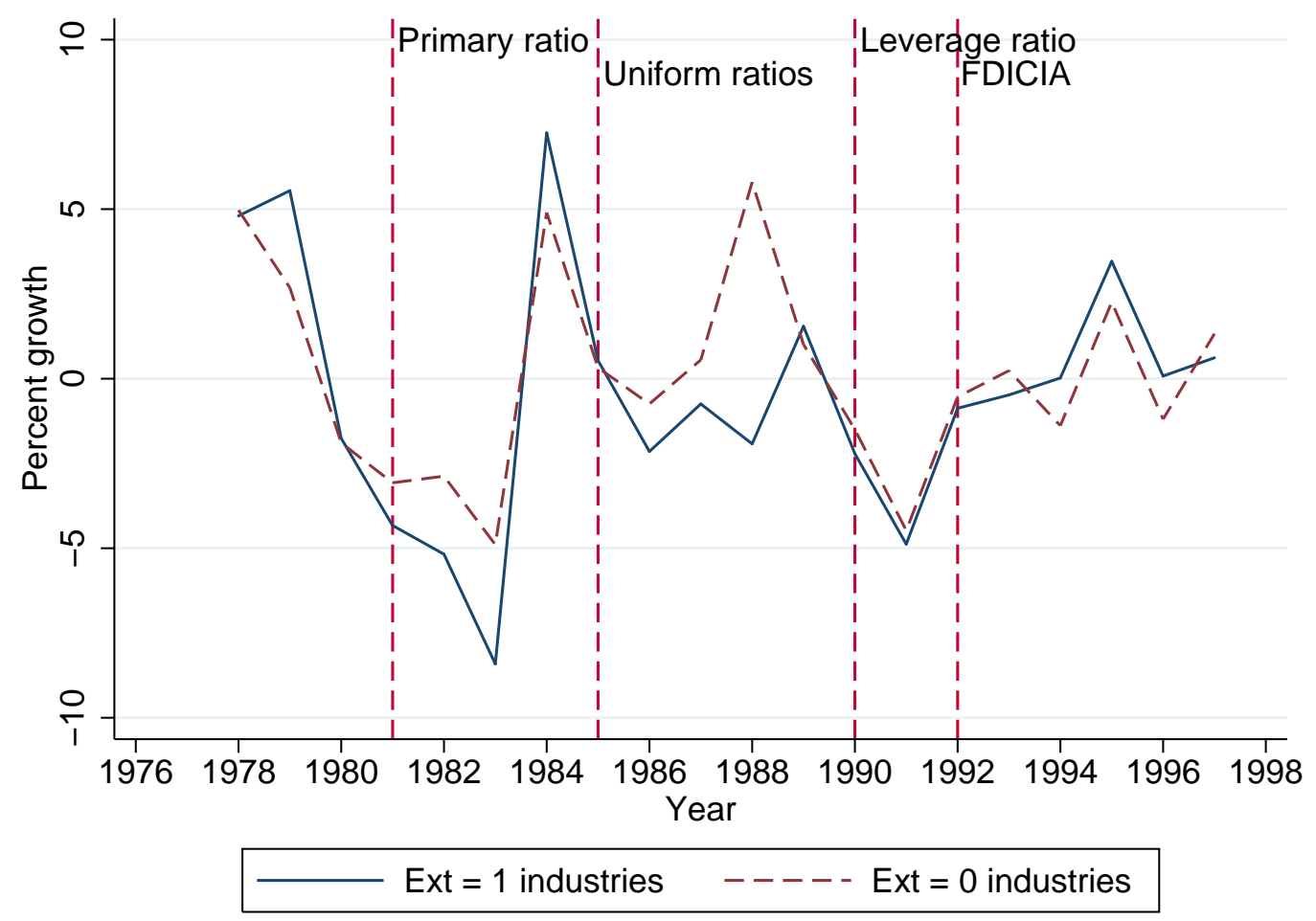

Notes: Ext $=1$ industries are manufacturing industries dependent on external sources of financing. Ext $=0$ industries are manufacturing industries not dependent on external sources of funding. A manufacturing industry (at the two-digit SIC code level) is classified as being dependent on external finance if its Rajan-Zingales measure lies above the median among manufacturing industries, as in Cetorelli and Strahan (2006). Source: The U.S. Census County Business Patterns Survey and Compustat. 
Figure 3: Employment Growth at a Industry-State Level

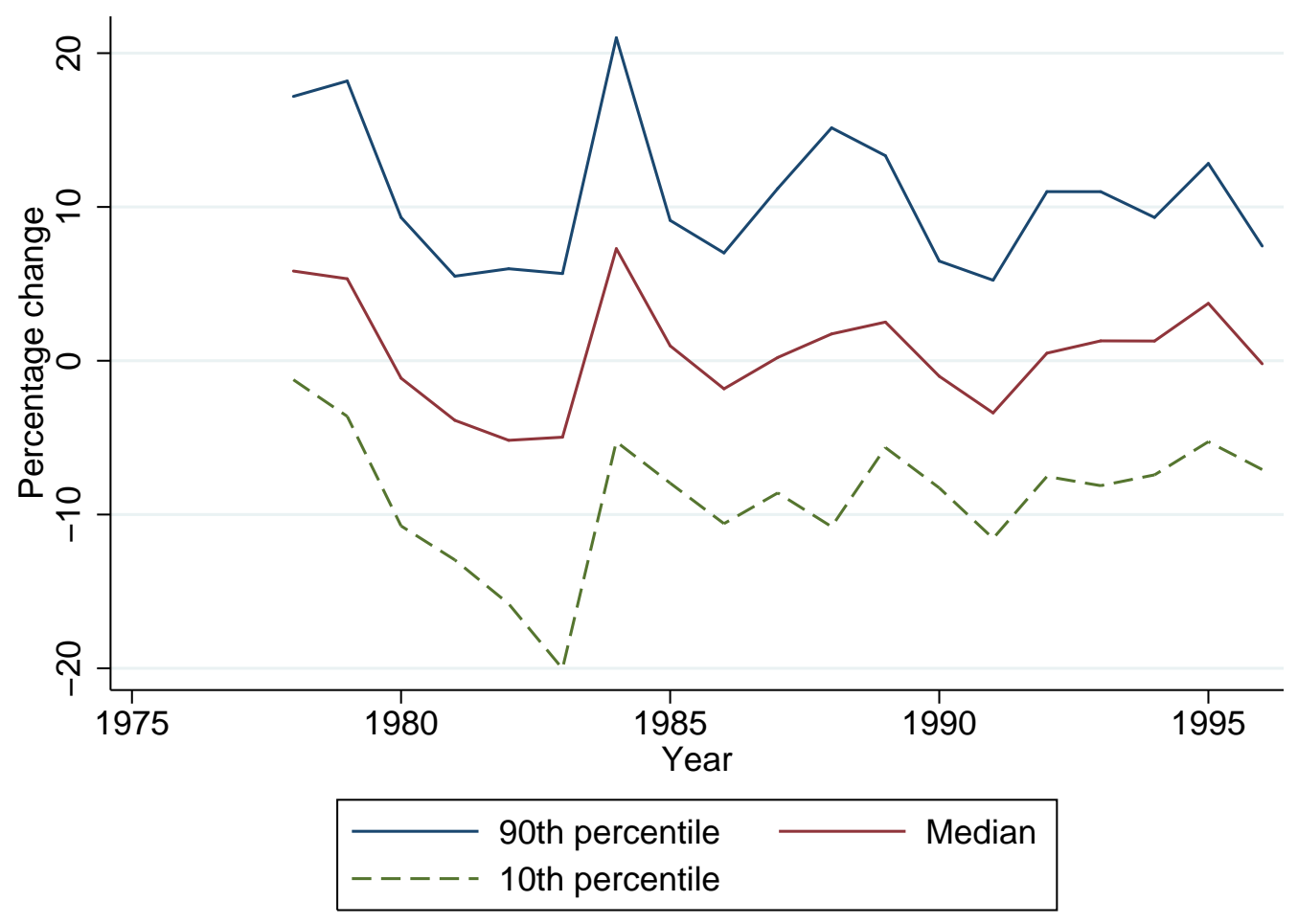

Notes: Percentiles are based on the 668 state-industries in our sample. Source: The U.S. Census County Business Patterns Survey. 
Figure 4: Changes in Tangible Capital Ratios at a State Level

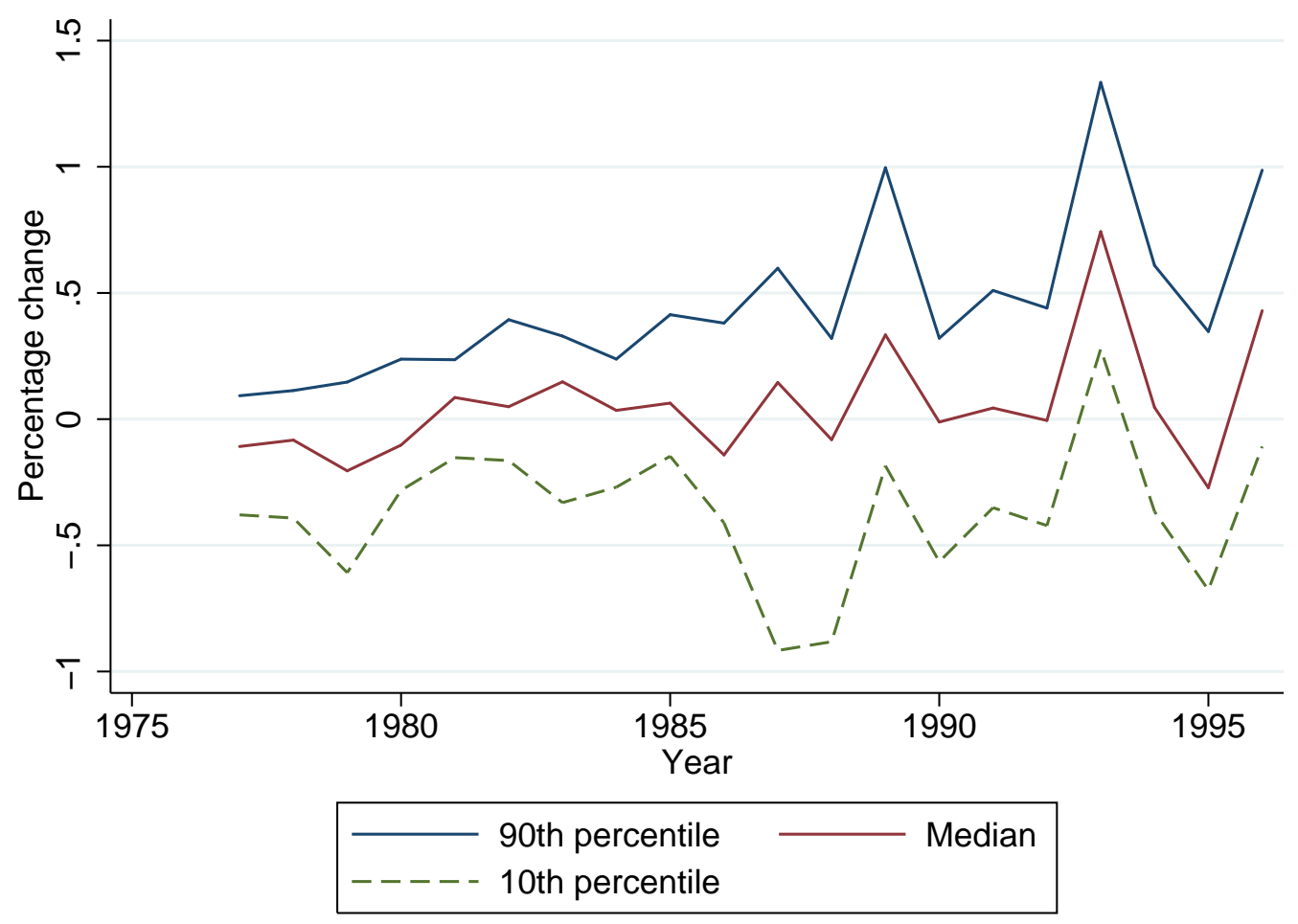

Notes: Percentiles are based on the 50 states and the District of Columbia. Source: National Information Center (NIC) and Call Reports. 
Table 1: Required Capital Ratios by Bank Type over Time (Percent)

\begin{tabular}{lccccc}
\hline \hline & \multicolumn{3}{c}{ Primary ratio } & \multicolumn{2}{c}{ Leverage Ratio } \\
& $1981-82$ & $1983-84$ & $1985-89$ & $1990-91$ & $1992-97$ \\
\hline Multinational bank & $a$ & 5 & 5.5 & 3 & 5 \\
Regional bank & 5 & 5 & 5.5 & 3 & 5 \\
Community bank & 6 & 6 & $5.5^{b}$ & 3 & 5 \\
\hline \hline
\end{tabular}

Notes: (a) For multinational banks, the primary ratio requirement was not defined in the 1981-82 period. The exclusion of this period from analysis does not affect the results. (b) Capital regulation was eased in 1985 for community banks only. 
Table 2: Results for Tangible Capital Ratios Explained by Bank Specifics and Capital Regulation

\begin{tabular}{|c|c|c|c|}
\hline \multicolumn{4}{|c|}{ CapRatio,$t$} \\
\hline \multicolumn{2}{|c|}{ Bank specifics } & \multicolumn{2}{|c|}{ Capital regulation } \\
\hline CapRatiob,t-1 & $\begin{array}{c}0.720^{* * *} \\
(82.366)\end{array}$ & PrimRatiot $_{t}$ & $\begin{array}{l}0.182^{\text {*** }} \\
(5.969)\end{array}$ \\
\hline CapRatio $_{b, t-2}$ & $\begin{array}{c}-0.050^{* * *} \\
(-11.649)\end{array}$ & PrimRatio $_{t} \times$ ResRatio $_{b, t}$ & $\begin{array}{l}-0.133^{\text {*** }} \\
(-8.833)\end{array}$ \\
\hline $\log \left(A_{s e t} s_{b, t}\right)$ & $\begin{array}{c}-0.532^{* * *} \\
(-21.578)\end{array}$ & PrimRatio $Q_{b, t+2}$ & $\begin{array}{l}0.010^{\text {*** }} \\
(6.414)\end{array}$ \\
\hline LoanRatio $_{b, t}$ & $\begin{array}{c}0.001 \\
(0.840)\end{array}$ & $\operatorname{PrimRatio} Q_{b, t+1}$ & $\begin{array}{c}0.032^{\text {*** }} \\
(18.440)\end{array}$ \\
\hline \multirow[t]{4}{*}{ ResRatio $_{b, t}$} & $\begin{array}{c}-0.000 \\
(-0.021)\end{array}$ & $\operatorname{PrimRatio}_{b, t}$ & $\begin{array}{l}0.023^{\text {*** }} \\
(9.603)\end{array}$ \\
\hline & & LevRatio $Q_{t+2}$ & $\begin{array}{c}0.072^{* * *} \\
(28.840)\end{array}$ \\
\hline & & LevRatio $Q_{t+1}$ & $\begin{array}{c}0.083^{* * *} \\
(31.475)\end{array}$ \\
\hline & & LevRatioQ $Q_{t}$ & $\begin{array}{l}0.081^{* * *} \\
(28.939)\end{array}$ \\
\hline \multicolumn{2}{|c|}{ Num. of observations } & 226362 & \\
\hline \multicolumn{2}{|c|}{ Num. of clusters } & 16811 & \\
\hline \multicolumn{2}{|l|}{ R-sq. overall } & 0.78 & \\
\hline \multicolumn{2}{|l|}{ R-sq. within } & 0.57 & \\
\hline \multicolumn{2}{|l|}{ R-sq. between } & 0.86 & \\
\hline
\end{tabular}

Notes: PrimRatio $t$ is the dummy variable for the primary ratio regulatory regime, which was in effect between 1981 and 1989. Coefficients are reported along with $t$ -statistics in parentheses. Bank fixed effects are included. Errors are robust to heteroskedasticity and clustered at the bank level. $* * *$ indicates significance at the 1 percent confidence level, ** at the 5 percent level, and $*$ at the 10 percent level. 
Table 3: Summary Statistics at Industry-State Level (1977-97, percent)

\begin{tabular}{lcc}
\hline \hline & Mean & Stand. Dev. \\
\hline Industries dependent on external finance & & \\
Growth in employment & 0.9 & 10.5 \\
Growth in the number of firms & 1.5 & 6.8 \\
Growth in the average size of firms (employees per firm) & -0.3 & 11.1 \\
& & \\
& & \\
Industries not dependent on external finance & 1.0 & 11.0 \\
Growth in employment & 1.4 & 6.0 \\
Growth in the number of firms & -0.3 & 10.5 \\
Growth in the average size of firms (employees per firm) \\
\hline \hline
\end{tabular}

Table 4: Summary Statistics at State Level (1976-96, percent)

\begin{tabular}{lcc}
\hline \hline & Mean & Stand. Dev. \\
\hline Change in tangible capital ratio & 0.05 & 0.69 \\
Change in loan loss reserves to total loans & 0.06 & 0.46 \\
Change in HHI (sum of squared local market deposit share) & 0.03 & 1.85 \\
Growth in real gross state product (billions of 2005 dollars) & 3.10 & 4.12 \\
\hline \hline
\end{tabular}


Table 5: Results for Growth in All Firms Explained by the Baseline Model

\begin{tabular}{|c|c|c|c|}
\hline & $\begin{array}{c}(1) \\
\Delta \text { Employment }_{s, t}\end{array}$ & $\begin{array}{c}(2) \\
\Delta N \text { umber of Firms } s_{s, t}\end{array}$ & $\begin{array}{c}\text { (3) } \\
\Delta \text { Size of Firms } s_{s, t}\end{array}$ \\
\hline External $_{i} \times \Delta$ CapRatio $_{s, t-1}$ & $\begin{array}{c}-0.647^{*} \\
(-1.729)\end{array}$ & $\begin{array}{c}0.084 \\
(0.345)\end{array}$ & $\begin{array}{c}-0.801^{* *} \\
(-2.054)\end{array}$ \\
\hline$\Delta$ CapRatio $_{s, t-1}$ & $\begin{array}{l}-0.032 \\
(-0.124)\end{array}$ & $\begin{array}{l}-0.152 \\
(-1.009)\end{array}$ & $\begin{array}{c}0.126 \\
(0.505)\end{array}$ \\
\hline External $_{i} \times \Delta$ ResRatio $_{s, t-1}$ & $\begin{array}{l}-0.256 \\
(-0.553)\end{array}$ & $\begin{array}{c}0.247 \\
(0.939)\end{array}$ & $\begin{array}{l}-0.401 \\
(-0.951)\end{array}$ \\
\hline$\Delta$ ResRatio $_{s, t-1}$ & $\begin{array}{c}0.248 \\
(0.914)\end{array}$ & $\begin{array}{l}-0.376^{* *} \\
(-2.293)\end{array}$ & $\begin{array}{c}0.528^{*} \\
(1.861)\end{array}$ \\
\hline External $_{i} \times \Delta H H I_{s, t-1}$ & $\begin{array}{c}0.016 \\
(0.098)\end{array}$ & $\begin{array}{l}-0.206^{* *} \\
(-2.430)\end{array}$ & $\begin{array}{c}0.238 \\
(1.598)\end{array}$ \\
\hline$\Delta H H I_{s, t-1}$ & $\begin{array}{c}0.120 \\
(1.080)\end{array}$ & $\begin{array}{l}0.164^{* * *} \\
(2.751)\end{array}$ & $\begin{array}{l}-0.055 \\
(-0.676)\end{array}$ \\
\hline External $_{i} \times$ Interstate $_{s, t-1}$ & $\begin{array}{l}-1.452^{*} \\
(-1.672)\end{array}$ & $\begin{array}{l}0.210 \\
(0.414)\end{array}$ & $\begin{array}{l}-1.646^{*} \\
(-1.810)\end{array}$ \\
\hline Interstate $_{s, t-1}$ & $\begin{array}{c}0.195 \\
(0.325)\end{array}$ & $\begin{array}{l}-0.163 \\
(-0.450)\end{array}$ & $\begin{array}{c}0.424 \\
(0.712)\end{array}$ \\
\hline External $_{i} \times$ Intrastate $_{s, t-1}$ & $\begin{array}{l}-0.298 \\
(-0.368)\end{array}$ & $\begin{array}{l}-0.070 \\
(-0.149)\end{array}$ & $\begin{array}{l}-0.321 \\
(-0.408)\end{array}$ \\
\hline Intrastate $_{s, t-1}$ & $\begin{array}{c}1.107^{*} \\
(1.798)\end{array}$ & $\begin{array}{c}0.179 \\
(0.580)\end{array}$ & $\begin{array}{c}0.896 \\
(1.578)\end{array}$ \\
\hline$\Delta \operatorname{Real} S G P_{s, t-1}$ & $\begin{array}{l}-1.806 \\
(-0.417)\end{array}$ & $\begin{array}{l}8.013^{* * *} \\
(3.489)\end{array}$ & $\begin{array}{l}-10.163^{* * *} \\
(-2.721)\end{array}$ \\
\hline Num. of observations & 13360 & 13360 & 13360 \\
\hline Num. of clusters & 668 & 668 & 668 \\
\hline R-sq. overall & 0.25 & 0.21 & 0.25 \\
\hline
\end{tabular}

Notes: Growth in left-hand-side variables and real gross state product are in percentages.

External is an indicator for industries dependent on external finance based on Cetorelli and Strahan (2006). $\Delta$ CapRatio is the change in the state-level tangible capital ratio; $\Delta$ ResRatio is the change in the state-level loan loss-reserves-to-loans ratio, and $\Delta H H I$ is the change in the state-level deposit-based Herfindahl-Hirschman; all of these are multiplied by 100. Interstate is an indicator for the year in which a state has deregulated interstate bank branching; Intrastate is an indicator for the year in which a state deregulated intrastate bank branching. Coefficients are reported along with $t$-statistics in parentheses. Industry $\times$ State and Industry $\times$ Year fixed effects are included. Errors are robust to heteroskedasticity and clustered at the industry-state level. ${ }^{* *}$ indicates significance at the 1 percent confidence level, ${ }^{* *}$ at the 5 percent level, and $*$ at the 10 percent level. 
Table 6: Results for Growth in All Firms Explained by the Main Model

\begin{tabular}{|c|c|c|c|}
\hline & $\begin{array}{c}(1) \\
\Delta \text { Employment }_{s, t}\end{array}$ & $\begin{array}{c}(2) \\
\Delta N \text { umber of Firms } s_{s, t}\end{array}$ & $\begin{array}{c}\text { (3) } \\
\Delta \text { Size of Firms } s_{s, t}\end{array}$ \\
\hline External $_{i} \times \Delta$ CapRatio $_{s, t-1}$ & $\begin{array}{l}-0.696^{*} \\
(-1.897)\end{array}$ & $\begin{array}{c}0.178 \\
(0.713)\end{array}$ & $\begin{array}{l}-0.953^{* *} \\
(-2.494)\end{array}$ \\
\hline External $_{i} \times \Delta$ ResRatio $_{s, t-1}$ & $\begin{array}{l}-0.415 \\
(-0.984)\end{array}$ & $\begin{array}{c}0.201 \\
(0.782)\end{array}$ & $\begin{array}{l}-0.525 \\
(-1.253)\end{array}$ \\
\hline External $_{i} \times \Delta H H I_{s, t-1}$ & $\begin{array}{l}-0.049 \\
(-0.290)\end{array}$ & $\begin{array}{l}-0.202^{* * *} \\
(-2.658)\end{array}$ & $\begin{array}{c}0.167 \\
(1.074)\end{array}$ \\
\hline External $_{i} \times$ Interstate $_{s, t-1}$ & $\begin{array}{l}-1.150 \\
(-1.304)\end{array}$ & $\begin{array}{l}-0.025 \\
(-0.053)\end{array}$ & $\begin{array}{l}-1.117 \\
(-1.184)\end{array}$ \\
\hline External $_{i} \times$ Intrastate $_{s, t-1}$ & $\begin{array}{l}-0.246 \\
(-0.304)\end{array}$ & $\begin{array}{l}-0.087 \\
(-0.201)\end{array}$ & $\begin{array}{l}-0.257 \\
(-0.332)\end{array}$ \\
\hline Num. of observations & 13360 & 13360 & 13360 \\
\hline Num. of clusters & 668 & 668 & 668 \\
\hline R-sq. overall & 0.23 & 0.16 & 0.23 \\
\hline
\end{tabular}

Notes: Growth in left-hand-side variables is in percentages. External is an indicator for industries dependent on external finance based on Cetorelli and Strahan (2006). $\Delta$ CapRatio is the change in the state-level tangible capital ratio; $\Delta$ ResRatio is the change in the statelevel loan loss-reserves-to-loans ratio, and $\Delta H H I$ is the change in the state-level deposit-based Herfindahl-Hirschman; all of these are multiplied by 100. Interstate is an indicator for the year in which a state has deregulated interstate bank branching; Intrastate is an indicator for the year in which a state deregulated intrastate bank branching. Coefficients are reported along with $t$-statistics in parentheses. Industry $\times$ State, Industry $\times$ Year, and State $\times Y$ ear fixed effects are included. Errors are robust to heteroskedasticity and clustered at the industry-state level. *** indicates significance at the 1 percent confidence level, ${ }^{* *}$ at the 5 percent level, and $*$ at the 10 percent level. 
Table 7: Results for Growth in All Firms in States with a Small Share of Community Banks

\begin{tabular}{lccc}
\hline \hline & $(1)$ & $(2)$ & $(3)$ \\
& $\Delta$ Employment $_{s, t}$ & $\Delta$ Number of Firms $_{s, t}$ & $\Delta$ Size of Firms $_{s, t}$ \\
\hline External $_{i} \times \Delta$ CapRatio $_{s, t-1}$ & $-0.783^{* *}$ & 0.064 & $-0.924^{* *}$ \\
& $(-2.025)$ & $(0.245)$ & $(-2.350)$ \\
External $_{i} \times \Delta$ ResRatio $_{s, t-1}$ & -0.239 & $0.488^{* *}$ & -0.679 \\
& $(-0.525)$ & $(1.966)$ & $(-1.595)$ \\
External $_{i} \times \Delta$ HHI $_{s, t-1}$ & -0.036 & $-0.171^{* *}$ & 0.148 \\
& $(-0.215)$ & $(-2.258)$ & $(0.915)$ \\
External $_{i} \times$ Interstate $_{s, t-1}$ & $-1.863^{* *}$ & -0.201 & $-1.661^{* *}$ \\
& $(-2.387)$ & $(-0.409)$ & $(-2.032)$ \\
External $_{i} \times$ Intrastate $_{s, t-1}$ & -0.312 & -0.123 & -0.222 \\
& $(-0.334)$ & $(-0.252)$ & $(-0.253)$ \\
& 10497 & 10497 & 10497 \\
Num. of observations & 644 & 644 & 644 \\
Num. of clusters & 0.18 & 0.10 & 0.13 \\
R-sq. overall & & &
\end{tabular}

Notes: Results are only for state-years where the share of deposits supplied by community banks is smaller than 80 percent. Growth in left-hand-side variables is in percentages. External is an indicator for industries dependent on external finance based on Cetorelli and Strahan (2006). $\Delta$ CapRatio is the change in the state-level tangible capital ratio; $\Delta$ ResRatio is the change in the state-level loan loss-reserves-to-loans ratio, and $\triangle H H I$ is the change in the state-level depositbased Herfindahl-Hirschman; all of these are multiplied by 100. Interstate is an indicator for the year in which a state has deregulated interstate bank branching; Intrastate is an indicator for the year in which a state deregulated intrastate bank branching. Coefficients are reported along with $t$-statistics in parentheses. Industry $\times$ State, Industry $\times$ Year, and State $\times Y$ ear fixed effects are included. Errors are robust to heteroskedasticity and clustered at the industry-state level. ${ }^{* * *}$ indicates significance at the 1 percent confidence level, ${ }^{* *}$ at the 5 percent level, and * at the 10 percent level. 
Table 8: Results for Growth in Small Firms

\begin{tabular}{lccc}
\hline \hline & $(1)$ & $(2)$ & $(3)$ \\
& $\Delta$ Employment $_{s, t}$ & $\Delta$ Number of Firms $_{s, t}$ & $\Delta$ Size of Firms $_{s, t}$ \\
\hline External $_{i} \times \Delta$ CapRatio $_{s, t-1}$ & $-0.798^{*}$ & 0.193 & $-0.994^{* * *}$ \\
& $(-1.657)$ & $(0.442)$ & $(-2.629)$ \\
External $_{i} \times \Delta$ ResRatio $_{s, t-1}$ & 0.169 & 0.345 & -0.148 \\
& $(0.302)$ & $(1.088)$ & $(-0.294)$ \\
External $_{i} \times \Delta$ HHI $_{s, t-1}$ & -0.267 & $-0.164^{* *}$ & -0.060 \\
& $(-1.500)$ & $(-2.017)$ & $(-0.406)$ \\
External $_{i} \times$ Interstate $_{s, t-1}$ & -0.760 & 0.252 & -1.103 \\
& $(-0.808)$ & $(0.414)$ & $(-1.305)$ \\
External $_{i} \times$ Intrastate $_{s, t-1}$ & 0.977 & 0.062 & 0.872 \\
& $(0.957)$ & $(0.105)$ & $(1.053)$ \\
& & & 13360 \\
Num. of observations & 13360 & 13360 & 668 \\
Num. of clusters & 668 & 668 & 0.13 \\
R-sq. overall & 0.11 & 0.19 & \\
\hline \hline Not & & &
\end{tabular}

Notes: Results are for growth in employment, the number of firms, and the average size of firms in the employment size class of fewer than 100 employees. Growth in left-hand-side variables is in percentages. External is an indicator for industries dependent on external finance based on Cetorelli and Strahan (2006). $\Delta$ CapRatio is the change in the state-level tangible capital ratio; $\Delta$ ResRatio is the change in the state-level loan loss-reserves-to-loans ratio, and $\triangle H H I$ is the change in the state-level deposit-based Herfindahl-Hirschman; all of these are multiplied by 100 . Interstate is an indicator for the year in which a state has deregulated interstate bank branching; Intrastate is an indicator for the year in which a state deregulated intrastate bank branching. Coefficients are reported along with $t$-statistics in parentheses. Industry $\times$ State, Industry $\times$ Year, and State $\times$ Year fixed effects are included. Errors are robust to heteroskedasticity and clustered at the industry-state level. $* * *$ indicates significance at the 1 percent confidence level, ${ }^{* *}$ at the 5 percent level, and ${ }^{*}$ at the 10 percent level. 
Table 9: Results for Growth in Large Firms

\begin{tabular}{lccc}
\hline \hline & $(1)$ & $(2)$ & $(3)$ \\
& $\Delta$ Employment $_{s, t}$ & $\Delta$ Number of Firms $_{s, t}$ & $\Delta$ Size of Firms $_{s, t}$ \\
\hline External $_{i} \times \Delta$ CapRatio $_{s, t-1}$ & 0.099 & 1.139 & -0.976 \\
& $(0.091)$ & $(0.914)$ & $(-1.379)$ \\
External $_{i} \times \Delta$ ResRatio $_{s, t-1}$ & $-3.308^{* * *}$ & $-2.759^{* *}$ & -0.347 \\
& $(-3.109)$ & $(-2.192)$ & $(-0.571)$ \\
External $_{i} \times \Delta$ HHI $_{s, t-1}$ & 0.022 & 0.170 & 0.072 \\
& $(0.059)$ & $(0.299)$ & $(0.276)$ \\
External $_{i} \times$ Interstate $_{s, t-1}$ & 0.029 & 1.133 & -0.558 \\
& $(0.016)$ & $(0.623)$ & $(-0.495)$ \\
External $_{i} \times$ Intrastate $_{s, t-1}$ & -1.030 & -2.059 & 0.045 \\
& $(-0.516)$ & $(-0.896)$ & $(0.050)$ \\
& 13204 & 13204 & 13204 \\
Num. of observations & 668 & 668 & 668 \\
Num. of clusters & 0.07 & 0.06 & 0.06 \\
R-sq. overall & & & \\
\hline \hline
\end{tabular}

Notes: Results are for growth in employment, the number of firms, and the average size of firms in the employment size class of more than 99 but fewer than 500 employees. Growth in left-hand-side variables is in percentages. External is an indicator for industries dependent on external finance based on Cetorelli and Strahan (2006). $\Delta$ CapRatio is the change in the state-level tangible capital ratio; $\Delta$ ResRatio is the change in the state-level loan loss-reservesto-loans ratio, and $\triangle H H I$ is the change in the state-level deposit-based Herfindahl-Hirschman; all of these are multiplied by 100. Interstate is an indicator for the year in which a state has deregulated interstate bank branching; Intrastate is an indicator for the year in which a state deregulated intrastate bank branching. Coefficients are reported along with $t$-statistics in parentheses. Industry $\times$ State, Industry $\times$ Year, and State $\times$ Year fixed effects are included. Errors are robust to heteroskedasticity and clustered at the industry-state level. *** indicates significance at the 1 percent confidence level, ${ }^{* *}$ at the 5 percent level, and ${ }^{*}$ at the 10 percent level. 
Table 10: Results for Growth in Small Firms in States with a Smaller Share of Community Banks

\begin{tabular}{|c|c|c|c|}
\hline & $\begin{array}{c}(1) \\
\Delta \text { Employment }_{s, t}\end{array}$ & $\begin{array}{c}(2) \\
\Delta \text { Number of Firms } s_{s, t}\end{array}$ & $\begin{array}{c}(3) \\
\Delta \text { Size of Firms } s_{s, t}\end{array}$ \\
\hline External $_{i} \times \Delta$ CapRatio $_{s, t-1}$ & $\begin{array}{l}-0.906^{*} \\
(-1.722)\end{array}$ & $\begin{array}{c}0.025 \\
(0.053)\end{array}$ & $\begin{array}{l}-0.895^{* *} \\
(-2.210)\end{array}$ \\
\hline External $_{i} \times \Delta$ ResRatio $_{s, t-1}$ & $\begin{array}{c}0.354 \\
(0.591)\end{array}$ & $\begin{array}{l}0.642^{* *} \\
(2.020)\end{array}$ & $\begin{array}{l}-0.345 \\
(-0.693)\end{array}$ \\
\hline External $_{i} \times \Delta H H I_{s, t-1}$ & $\begin{array}{l}-0.292^{*} \\
(-1.701)\end{array}$ & $\begin{array}{l}-0.133^{*} \\
(-1.690)\end{array}$ & $\begin{array}{l}-0.129 \\
(-0.844)\end{array}$ \\
\hline External $_{i} \times$ Interstate $_{s, t-1}$ & $\begin{array}{l}-0.470 \\
(-0.453)\end{array}$ & $\begin{array}{c}0.025 \\
(0.038)\end{array}$ & $\begin{array}{l}-0.445 \\
(-0.523)\end{array}$ \\
\hline External $_{i} \times$ Intrastate $_{s, t-1}$ & $\begin{array}{c}0.248 \\
(0.219)\end{array}$ & $\begin{array}{l}-0.194 \\
(-0.292)\end{array}$ & $\begin{array}{c}0.435 \\
(0.506)\end{array}$ \\
\hline Num. of observations & 10497 & 10497 & 10497 \\
\hline Num. of clusters & 644 & 644 & 644 \\
\hline R-sq. overall & 0.09 & 0.15 & 0.10 \\
\hline
\end{tabular}

Notes: Results are for growth in employment, the number of firms, and the average size of firms in the employment size class of fewer than 100 employees and for state-years where the share of deposits supplied by community banks is smaller than 80 percent. Growth in left-hand-side variables is in percentages. External is an indicator for industries dependent on external finance based on Cetorelli and Strahan (2006). $\Delta$ CapRatio is the change in the state-level tangible capital ratio; $\Delta$ ResRatio is the change in the state-level loan loss-reserves-to-loans ratio, and $\triangle H H I$ is the change in the state-level deposit-based Herfindahl-Hirschman; all of these are multiplied by 100 . Interstate is an indicator for the year in which a state has deregulated interstate bank branching; Intrastate is an indicator for the year in which a state deregulated intrastate bank branching. Coefficients are reported along with $t$-statistics in parentheses. Industry $\times$ State, Industry $\times$ Year, and State $\times$ Year fixed effects are included. Errors are robust to heteroskedasticity and clustered at the industry-state level. $* * *$ indicates significance at the 1 percent confidence level, ${ }^{* *}$ at the 5 percent level, and ${ }^{*}$ at the 10 percent level. 
Table 11: Results for Growth in All Firms: Tangible Capital Ratios Weighted by the Number of Branches

\begin{tabular}{|c|c|c|c|}
\hline & $\begin{array}{c}(1) \\
\Delta \text { Employment }_{s, t}\end{array}$ & $\begin{array}{c}(2) \\
\Delta N u m b e r \text { of Firms } \\
s, t\end{array}$ & $\begin{array}{c}(3) \\
\Delta \text { Size of Firms } s_{s, t}\end{array}$ \\
\hline External $_{i} \times \Delta$ CapRatio $2_{s, t-1}$ & $\begin{array}{r}-1.275^{*} \\
(-1.864)\end{array}$ & $\begin{array}{c}0.211 \\
(0.485)\end{array}$ & $\begin{array}{l}-1.550^{* *} \\
(-2.097)\end{array}$ \\
\hline External $_{i} \times \Delta$ ResRatio $_{s, t-1}$ & $\begin{array}{c}0.332 \\
(0.502)\end{array}$ & $\begin{array}{c}0.423 \\
(1.026)\end{array}$ & $\begin{array}{l}-0.019 \\
(-0.028)\end{array}$ \\
\hline External $_{i} \times \Delta H H I_{s, t-1}$ & $\begin{array}{l}-0.041 \\
(-0.248)\end{array}$ & $\begin{array}{l}-0.202^{* * *} \\
(-2.660)\end{array}$ & $\begin{array}{c}0.173 \\
(1.119)\end{array}$ \\
\hline External $_{i} \times$ Interstate $_{s, t-1}$ & $\begin{array}{l}-1.269 \\
(-1.434)\end{array}$ & $\begin{array}{c}0.002 \\
(0.004)\end{array}$ & $\begin{array}{l}-1.243 \\
(-1.310)\end{array}$ \\
\hline External $_{i} \times$ Intrastate $_{s, t-1}$ & $\begin{array}{l}-0.205 \\
(-0.253)\end{array}$ & $\begin{array}{l}-0.093 \\
(-0.214)\end{array}$ & $\begin{array}{l}-0.209 \\
(-0.268)\end{array}$ \\
\hline Num. of observations & 13360 & 13360 & 13360 \\
\hline Num. of clusters & 668 & 668 & 668 \\
\hline R-sq. overall & 0.23 & 0.17 & 0.24 \\
\hline
\end{tabular}

Notes: Growth in left-hand-side variables is in percentages. External is an indicator for industries dependent on external finance based on Cetorelli and Strahan (2006). $\Delta$ CapRatio is the change in the state-level tangible capital ratio; $\Delta$ ResRatio is the change in the statelevel loan loss-reserves-to-loans ratio, and $\triangle H H I$ is the change in the state-level deposit-based Herfindahl-Hirschman; all of these are multiplied by 100 . Inter state is an indicator for the year in which a state has deregulated interstate bank branching; Intrastate is an indicator for the year in which a state deregulated intrastate bank branching. Coefficients are reported along with $t$-statistics in parentheses. Industry $\times$ State, Industry $\times$ Year, and State $\times$ Year fixed effects are included. Errors are robust to heteroskedasticity and clustered at the industry-state level. *** indicates significance at the 1 percent confidence level, ${ }^{* *}$ at the 5 percent level, and $*$ at the 10 percent level. 
Table 12: Results for Growth in All Firms: Tangible Capital Ratios Weighted by the Amounts of Local Deposits

\begin{tabular}{|c|c|c|c|}
\hline & $\begin{array}{c}(1) \\
\Delta \text { Employment }_{s, t}\end{array}$ & $\begin{array}{c}(2) \\
\Delta N \text { umber of Firms } \\
s, t\end{array}$ & $\begin{array}{c}(3) \\
\Delta \text { Size of Firms } \\
s, t\end{array}$ \\
\hline External $_{i} \times \Delta$ CapRatio $3_{s, t-1}$ & $\begin{array}{l}-0.682^{*} \\
(-1.863)\end{array}$ & $\begin{array}{c}0.200 \\
(0.791)\end{array}$ & $\begin{array}{l}-0.971^{* *} \\
(-2.568)\end{array}$ \\
\hline External $_{i} \times \Delta$ ResRatio $_{s, t-1}$ & $\begin{array}{l}-0.488 \\
(-1.012)\end{array}$ & $\begin{array}{c}0.078 \\
(0.267)\end{array}$ & $\begin{array}{l}-0.458 \\
(-0.932)\end{array}$ \\
\hline External $_{i} \times \Delta H H I_{s, t-1}$ & $\begin{array}{l}-0.055 \\
(-0.329)\end{array}$ & $\begin{array}{l}-0.202^{* * *} \\
(-2.663)\end{array}$ & $\begin{array}{c}0.160 \\
(1.031)\end{array}$ \\
\hline External $_{i} \times$ Interstate $_{s, t-1}$ & $\begin{array}{l}-1.187 \\
(-1.348)\end{array}$ & $\begin{array}{c}0.010 \\
(0.022)\end{array}$ & $\begin{array}{l}-1.187 \\
(-1.256)\end{array}$ \\
\hline External $_{i} \times$ Intrastate $_{s, t-1}$ & $\begin{array}{l}-0.261 \\
(-0.323)\end{array}$ & $\begin{array}{l}-0.087 \\
(-0.200)\end{array}$ & $\begin{array}{l}-0.275 \\
(-0.356)\end{array}$ \\
\hline Num. of observations & 13360 & 13360 & 13360 \\
\hline Num. of clusters & 668 & 668 & 668 \\
\hline R-sq. overall & 0.24 & 0.17 & 0.23 \\
\hline
\end{tabular}

Notes: Growth in left-hand-side variables is in percentages. External is an indicator for industries dependent on external finance based on Cetorelli and Strahan (2006). $\Delta$ CapRatio is the change in the state-level tangible capital ratio; $\Delta$ ResRatio is the change in the statelevel loan loss-reserves-to-loans ratio, and $\triangle H H I$ is the change in the state-level deposit-based Herfindahl-Hirschman; all of these are multiplied by 100. Interstate is an indicator for the year in which a state has deregulated interstate bank branching; Intrastate is an indicator for the year in which a state deregulated intrastate bank branching. Coefficients are reported along with $t$-statistics in parentheses. Industry $\times$ State, Industry $\times Y$ ear, and State $\times Y$ ear fixed effects are included. Errors are robust to heteroskedasticity and clustered at the industry-state level. ${ }^{* * *}$ indicates significance at the 1 percent confidence level, ${ }^{* *}$ at the 5 percent level, and * at the 10 percent level. 


\section{Appendix. Additional Robustness Checks}

In this appendix, we offer several robustness checks for the main model estimated for employment.

First, we estimate the main model with a lagged dependent term included. While the fixed effects used in our panel structure are likely correlated with the explanatory variables, the presence of a lagged dependent variable gives rise to "dynamic panel bias," as in Nickell (1981). However, since the rate at which this bias disappears is $1 / T$, we believe that our 20-year sample period alleviates if not eliminates this endogeneity problem 41 As column (1) in Table A1 suggests, growth in employment exhibits little persistence, so the propagation mechanism from a one-time capital shock is weak.

Second, we exclude the three largest states from the sample and estimate the main model. For the remaining states, this exclusion puts more weight on changes in the capital positions of out-of-state banks that lend to firms in a given smaller state. In other words, this sample restriction should strengthen the identification approach. The results, shown in column 2 of Table A1, are very similar to those in column 1 of Table 6. The similarity in the results further validates our identification approach.

Third, we tie changes in tangible capital ratios more closely to changes in capital regulation. As the results in Table 2 suggest, many factors might have contributed to commercial banks' capital pressures, but stricter capital requirements played a major role. Therefore, we would like to gauge the effects of tangible capital ratios driven by capital regulation on employment. We aggregate tangible capital ratios that are predicted by Equation 1, conditional on capital regulation parameters and some bank specifics, and then use the resultant predicted tangible capital ratios at a state level as the main explanatory variable in the main model. The results, shown in column 3 of Table A1, are very similar to those in column 1 of Table 6 .

Separately, Table A2 provides definitions of various capital ratios to help motivate our choice of the explained variable.

\footnotetext{
${ }^{41}$ We lost one year of observations because of the inclusion of the lagged dependent variable.
} 
Table A1: Results for Growth in All Firms: Some Robustness Checks

\begin{tabular}{|c|c|c|c|}
\hline & $\begin{array}{c}(1) \\
\Delta \text { Employment }_{s, t}\end{array}$ & $\begin{array}{c}(2) \\
\Delta \text { Employment }_{s, t}\end{array}$ & $\begin{array}{c}(3) \\
\Delta \text { Employment }_{s, t}\end{array}$ \\
\hline$\Delta$ Employment $_{s, t-1}$ & $\begin{array}{l}-0.130^{* * *} \\
(-9.145)\end{array}$ & & \\
\hline External $_{i} \times \Delta$ CapRatio $_{s, t-1}$ & $\begin{array}{l}-0.699^{*} \\
(-1.935)\end{array}$ & $\begin{array}{r}-0.699^{*} \\
(-1.898)\end{array}$ & $\begin{array}{l}-0.891^{*} \\
(-1.693)\end{array}$ \\
\hline External $_{i} \times \Delta$ ResRatio $_{s, t-1}$ & $\begin{array}{l}-0.453 \\
(-1.042)\end{array}$ & $\begin{array}{l}-0.264 \\
(-0.599)\end{array}$ & $\begin{array}{l}-0.257 \\
(-0.631)\end{array}$ \\
\hline External $_{i} \times \Delta H H I_{s, t-1}$ & $\begin{array}{l}-0.077 \\
(-0.455)\end{array}$ & $\begin{array}{c}-0.062 \\
(-0.358)\end{array}$ & $\begin{array}{l}-0.072 \\
(-0.418)\end{array}$ \\
\hline External $_{i} \times$ Interstate $_{s, t-1}$ & $\begin{array}{l}-1.248 \\
(-1.384)\end{array}$ & $\begin{array}{l}-1.219 \\
(-1.345)\end{array}$ & $\begin{array}{l}-0.940 \\
(-1.005)\end{array}$ \\
\hline External $_{i} \times$ Intrastate $_{s, t-1}$ & $\begin{array}{l}0.116 \\
(0.144)\end{array}$ & $\begin{array}{c}0.329 \\
(0.431)\end{array}$ & $\begin{array}{l}-0.186 \\
(-0.227)\end{array}$ \\
\hline Num. of observations & 12692 & 12360 & 12024 \\
\hline Num. of clusters & 668 & 618 & 668 \\
\hline R-sq. overall & 0.19 & 0.25 & 0.24 \\
\hline
\end{tabular}

Notes: (1) The regression includes a lagged dependent variable; because the series is not persistent, this term is omitted from all other regressions. (2) The sample excludes the three largest states (California, New York, and Texas) to strengthen the identification. (3) This specification relies on state-level tangible capital ratios that are constructed at a bank level using Equation 1 and then aggregated using Equation 2. The growth in lefthand-side variables is in percentages. External is an indicator for industries dependent on external finance based on Cetorelli and Strahan (2006). $\Delta$ CapRatio is the change in the state-level tangible capital ratio; $\Delta$ ResRatio is the change in the state-level loan loss-reserves-to-loans ratio, and $\Delta H H I$ is the change in the state-level deposit-based Herfindahl-Hirschman; all of these are multiplied by 100. Interstate is an indicator for the year in which a state has deregulated interstate bank branching; Intrastate is an indicator for the year in which a state deregulated intrastate bank branching. Coefficients are reported along with $t$-statistics in parentheses. Industry $\times$ State, Industry $\times$ Year, and State $\times$ Year fixed effects are included. Errors are robust to heteroskedasticity and clustered at the industry-state level. *** indicates significance at the 1 percent confidence level, ${ }^{* *}$ at the 5 percent level, and ${ }^{*}$ at the 10 percent level. 


\section{Table A2: Definitions of Regulatory Capital Ratios}

\section{Primary Capital Ratio}

Total Capital Ratio

Tier 1 Risk-Based Capital Ratio

Total Risk-Based Capital Ratio

Leverage Ratio

Tangible Capital Ratio
Primary capital consisted of stockholders' equity, perpetual preferred stock, loan loss reserves, and certain debt instruments that must be converted to common or preferred stock at maturity. Intangible assets except mortgage servicing rights were deducted from both the denominator and the numerator for the ratio of primary capital to assets. Minimum primary capital ratios were introduced in 1981 for community and regional banks and in 1983 for multinational banks. Regulators set a uniform minimum level of the primary capital ratio in 1985 for all banks, thereby raising the minimum ratios for multinational and regional banks and lowering the ratio for community banks.

Total capital consisted of primary capital plus secondary capital instruments such as limited-life preferred stock and qualifying debt not included in primary capital. The denominator was the same as for the primary capital ratio. Regulatory minimum total capital ratios were introduced at the same time as those for the primary capital ratio.

Tier 1 capital consists of common equity, certain perpetual preferred stock, and minority interest in consolidated subsidiaries less certain intangible assets, such as goodwill, and net unrealized gains on investment account securities classified as available for sale. The Tier 1 capital ratio is defined as Tier 1 capital relative to risk-weighted assets and was partially introduced in 1989 before being fully adopted in 1992 in accordance with Basel I.

The total risk-based capital ratio is defined as Tier 1 and Tier 2 capital relative to risk-weighted assets. Tier 2 capital consists primarily of subordinated debt, preferred stock not included in Tier 1 capital, and loan loss reserves up to a cap of 1.25 percent of risk-weighted assets. The total capital ratio was introduced and adopted along with the Tier 1 capital ratio in accordance with Basel I.

The leverage ratio is the ratio of Tier 1 capital to average tangible assets, which is equal to total average consolidated assets less assets excluded from common equity in the calculation of Tier 1 capital. The leverage ratio was introduced in 1990.

The tangible capital ratio is the ratio of total equity minus intangible assets relative to total assets minus intangible assets. 